BESIO, Martín. "Aplicación del artículo 351 del Código Procesal Penal".

Polít. crim. Vol. 10, No 20 (Diciembre 2015), Art. 5, pp. 543-596.

[http://www.politicacriminal.cl/Vol_10/n_20/Vol10N20A5.pdf]

\title{
Aplicación del artículo 351 del Código Procesal Penal
}

\section{Application of article 351 of the Penal Procedure Code}

\author{
Dr. Martín Besio Hernández \\ Universidad Diego Portales \\ martinbesio@gmail.com
}

\section{Resumen}

Pese a su extendida presencia en las decisiones de condena y a la existencia de ciertos consensos generales a su respecto, subsisten todavía algunos núcleos problemáticos en la forma de entender $-\mathrm{y}$, por consiguiente, de aplicar- la regla de exasperación punitiva contemplada en el art. 351 del Código Procesal Penal para aquella pluralidad de delitos en concurso material que pueden estimarse como de una misma especie. Este trabajo pretende sistematizar y cuestionar algunas tendencias dogmáticas y jurisprudenciales que se han construido a su respecto.

Palabras clave: concurso real de delitos, delitos de una misma especie, exasperación de la pena.

\begin{abstract}
Despite its large presence in condemnation decisions and the existence of some general consensus on them, it still subsist some problematic issues in the way that the penalty increase rule set off in art. 351 of the Criminal Procedure Code must be understood and applied in case of overlapped offenses that might be considered of a same nature. This paper tries to rescue, systematize and controvert some jurisprudence and dogmatic tendencies constructed on this respect.
\end{abstract}

Keywords: overlapped offenses, offenses of the same nature, aggravation of punishment.

\section{Introducción.}

La respuesta primaria del sistema penal chileno a la comisión de varios ilícitos -fáctica y normativamente- independientes ejecutados por un mismo autor se traduce en la imposición conjunta o sucesiva a éste de tantas penas como infracciones se hayan ejecutado, salvo que se trate de ilícitos que compartan un mismo objeto de protección, pues en ese entonces -sólo en ese entonces- se prevé positivamente a través del art. 351 del Código Procesal Penal un sistema de tratamiento especial cuyo objetivo es morigerar esa respuesta original a través de la asignación de una única pena agravada, pero inferior a la primaria. 


\section{BESIO, Martín. “Aplicación del artículo 351 del Código Procesal Penal”.}

No obstante la vigencia permanente -aunque con algunos retoques menores- de dicho precepto en nuestra legislación, subsiste todavía un déficit relevante de consistencia sistemática en la forma en que se entiende y, en consecuencia, aplica en las decisiones de condena; carencia no sólo atribuible a la escasa atención dogmática generada a su respecto, sino que muy especialmente a la displicencia con que normalmente la jurisprudencia se enfrenta a éste y a otras reglas y problemas de individualización de la pena: un exiguo desarrollo argumental y una defensa impasible de la discrecionalidad judicial como resguardo frente a cualquier tipo de cuestionamiento jurisdiccional de las decisiones adoptadas.

En ese escenario este trabajo asume la pretensión de revisar y analizar críticamente, de la mano de sentencias relevantes, algunos de los principales problemas que aquejan a la regla de reiteración de delitos de una misma especie, vinculados principalmente con su régimen de operatividad.

\section{Fundamento.}

De acuerdo a la opinión tradicional y generalizada, el fundamento soporte del sistema de acumulación jurídica para delitos de una misma especie que prevé el art. 351 del Código Procesal Penal se encuentra fuertemente vinculado a la idea de humanidad de las penas ${ }^{1}$, esto es, a la morigeración del régimen punitivo -generalmente más gravoso y eventualmente excesivo- que importa para el condenado el sistema de acumulación material de las sanciones previsto en el art. 74 del Código Penal.

Dicho fundamento, con todo, debe ser matizado, pues si bien resulta evidente que el sistema de acumulación jurídica tiene un evidente objetivo normativo de atenuación de la respuesta penal que originalmente debe ser atribuida al condenado a través del modelo general de acumulación material, no alcanza, empero, a explicar su operatividad limitada exclusivamente a aquellos delitos que revistan la crucial condición de ser -entre ellos- de una misma especie, sin extender sus efectos a aquellos ilícitos que no afecten a un mismo bien jurídico (sea como se interprete esa cualidad en concreto), concurran o no con delitos que sí compartan dicha condición ${ }^{2}$.

\footnotetext{
${ }^{1}$ MATUS ACUÑA, Jean Pierre, "Proposiciones respecto de las cuestiones no resueltas por la ley 20.084 en materia de acumulación y orden de cumplimiento de las penas", Ius et Praxis, vol. 15, n 2 (2008), pp. 285306, p. 529, en: http://www.scielo.cl/pdf/iusetp/v14n2/art15.pdf [cit.: "Proposiciones]"; COUSO SALAS, Jaime, "Comentario previo a los Arts. 74 y 75. El régimen concursal chileno. Tratamiento doctrinario y jurisprudencial", en: COUSO, Jaime; HERNÁNDEZ, Héctor (Dirs.), Código Penal comentado, parte general. Doctrina y jurisprudencia, Santiago: Ed. AbeledoPerrot, 2011, pp. 625-666, pp. 650-651 [cit.: "Comentario"].

${ }^{2}$ Aunque el sistema de cuantificación que propone el art. 351 del Código Procesal Penal opera respecto de las “diversas infracciones" de una misma especie, expresión que podría entenderse en términos de una limitación operativa circunscrita al supuesto de que todas las infracciones materia del proceso reúnan esa cualidad, como lo entienden Solari/Rodríguez (SOLARI, Tito; RODRÍGUEZ, Luis, "Determinación de la pena en los casos de reiteración de delitos (Ámbito de aplicación del art. 509 del Código de Procedimiento Penal)", Revista de Derecho Pontificia Universidad Católica de Valparaíso, vol. III (1979), pp. 255-271, pp. 268-269 [cit.: "Determinación"]), aunque respecto del art. 509 del Código de Procedimiento Penal; nada impide entender, como sostiene Couso Salas ("Comentario", cit. nota n 1 , p. 653), postura a la que se ha sumado Oliver Calderón (OLIVER CALDERÓN, Guillermo, "La exasperación de la pena en el concurso material de delitos:
} 


\section{Polít. crim. Vol. 10, № 20 (Diciembre 2015), Art. 5, pp. 543-596. \\ [http://www.politicacriminal.cl/Vol_10/n_20/Vol10N20A5.pdf]}

En efecto, no hay duda que el régimen de acumulación jurídica supone un sistema privilegiado para el condenado, que queda en evidencia no sólo a partir del modelo de cuantificación que propone en abstracto (en comparación con la imposición conjunta o sucesiva de todas las penas de los delitos en concurso real), sino que -especialmente- en la medida que su operatividad en el caso concreto se encuentra condicionada expresamente al evento de que por su intermedio sea posible la imposición de una pena menor a aquella derivada del sistema general de acumulación material del art. 74 del Código Penal ${ }^{3}$. No obstante ello, si se admite que dicho tratamiento privilegiado tiene su fundamento en la necesidad de atenuación de la respuesta penal asignada a quien comete una pluralidad de delitos en concurso real -la idea de humanizar el régimen de imposición y cumplimiento de penas conjuntas o sucesivas- no se advierte la razón por la que tal necesidad de atenuación no se ha cristalizado normativamente para aquella pluralidad de infracciones que no son de una misma especie; admitiéndose respecto de éstas todo el rigor y exceso punitivo que se evita sólo para el evento en que los ilícitos compartan un mismo bien jurídico protegido. Alguna cualidad o característica especial -que hasta ahora desconocemos- presenta entonces la identidad del objeto de tutela, pues sólo a su respecto el sistema penal reconoce y gestiona la necesidad de disminución de la respuesta penal frente a una pluralidad delictiva.

De todos modos, si se acepta que es la idea de humanidad de las penas la que justifica el sistema del art. 351 del Código Procesal Penal ${ }^{4}$, ese objetivo se erige entonces como la

la reiteración de delitos de la misma especie”, Revista de Derecho (Valdivia), vol. 26, n 2 (diciembre 2013), pp. 167-188, p. 182, en: http://www.scielo.cl/pdf/revider/v26n2/art07.pdf [cit: "La exasperación"]), que dicha expresión refiere -y por tanto el régimen de reiteración se aplica- sólo respecto de aquellos delitos de una misma especie sin excluir su aplicación por la sola circunstancia de que éstos concurran con otros que no revistan dicha condición, de modo tal que la regla de reiteración producirá sus efectos sólo respecto de los delitos de una misma especie, generando una pena que luego se acumulará materialmente -conforme al régimen del art. 74 del Código Penal- a la pena o penas del delito o delitos que no sean de una misma especie.

${ }^{3}$ Sin perjuicio de la instauración positiva de una regla que impone la aplicación subsidiaria del sistema de acumulación material de las penas, existen algunos casos límite -generalmente vinculados a la imposición de sustitutivos penales - en que la determinación de lo que constituye una pena menor, proyección normativa de sanción que condiciona la aplicación del art. 351 del Código Procesal Penal (y en su caso del art. 74 del Código Penal) dista de ser unívoca; con todo, al menos tratándose de sustitutivos penales, la instauración relativamente reciente (Ley 20.603) de verdaderas penas sustitutivas -en reemplazo de los anteriores beneficios alternativos- ha despejado, al menos en principio, la problemática.

${ }^{4}$ Recientemente Contreras Guerrero (CONTRERAS GUERRERO, Pablo, "Una tesis para entender la medida de la pena en los casos de reiteración de delitos de la misma especie: análisis de las reglas penológicas contenidas en el artículo 351 del Código Procesal Penal a la luz del Principio de Proporcionalidad Constitucional", Polit. crim. vol. 9, $\mathrm{N}^{\circ} 18$ (diciembre 2014), pp. 614-667, pp. 615-617 y 640-646, en: http://www.politicacriminal.cl/Vol_09/n 18/Vol9N18A10.pdf [cit.: "Una tesis"]), ha cuestionado la tesis dogmática tradicional, proponiendo al principio de proporcionalidad como justificación material del sistema de reiteración previsto en el art. 351 del Código Procesal Penal, en términos de aseverar que su fundamento “(...) es evitar que la suma de meros hurtos alcance en su sanción una pena que, por su gravedad, sólo puede ser asociada a un delito tan grave como el homicidio, tanto en cuanto aquél tutela el bien jurídico probablemente más caro para el cuerpo social, esto es, la vida" (p. 617), sosteniendo, en esa misma línea, que la acumulación material de delitos de una misma especie generaría el problema -que estaría destinado a corregir el sistema de reiteración y del que se desprende entonces su justificación- que termina “(...) igualando valoraciones diversas (referidas tanto a los bienes jurídicos en sí como a su nivel de afectación), con lo cual se podría llegar al absurdo de afirmar que un homicidio simple es axiológicamente equivalente (tanto en cuanto su desvalor) en su significación de gravedad a tres robos con fuerza en bien nacional de uso 


\section{BESIO, Martín. “Aplicación del artículo 351 del Código Procesal Penal”.}

directriz guía de su interpretación, especialmente en lo que respecta al presupuesto base que condiciona su aplicación, a saber, la identidad de bien jurídico entre las infracciones que se integran a su alero 5 .

\section{Régimen de operatividad: problemas centrales de aplicación práctica.}

Desde la óptica de la praxis judicial, los principales problemas que presenta la interpretación y aplicación del art. 351 del Código Procesal Penal están constituidos por la forma en que debe realizarse el aumento en grado -imperativo en uno, facultativo en dos ${ }^{6}-$ propio de la exasperación punitiva y, vinculado con ello, por la determinación del momento $\mathrm{u}$ orden en que deben producir sus efectos sobre el marco penal -en el caso de que concurran- las circunstancias modificatorias de responsabilidad penal y otras reglas que

público, que seis delitos de daños equivalen a un delito de violación, o que diez delitos [de] lesiones menos graves equivalen a un delito de mutilación, o que diez delitos de daños simples equivalen a un delito de incendiar un edificio destinado a servir de morada, que no esté habitada (...)" (p. 641), justificando la exasperación en la "(...) reiteración, en tanto recaída en la comisión de un hecho ilícito (...)” (p. 641), dado que “(...) la mera repetición de acciones no alterará el valor del bien jurídico afectado, ni tampoco puede afirmarse que esa sola repetición importe un incremento significativo en la entidad de la lesión del bien jurídico" (pp. 640-641). Aunque los límites naturales asociados a este trabajo impiden un análisis acabado de dicha propuesta, debe destacarse que se basa en un juicio de proporcionalidad de carácter general y externo, en tanto adopta como referente los marcos penales abstractos de diferentes delitos que se comparan ex ante entre sí en circunstancias que la relación de proporcionalidad opera en concreto, respecto del hecho punible específico cometido por un autor determinado con todas sus circunstancias particulares y la pena que es posible de asignar a su respecto, sin referencia a otros delitos no ejecutados ni a sus penas. Por otra parte, los delitos propuestos como ejemplo para justificar el mandato de proporcionalidad que defendería la regla de reiteración se encuentran sancionados con penas abstractas tan distanciadas en la escala gradual respectiva que, por esa circunstancia, derivada precisamente de la proporcionalidad normativa individual existente entre cada tipo de delito con sus penas asociadas, validan la tesis del autor, pero tal presupuesto no se satisface en razón de la reiteración para todos los casos. Así, en otros escenarios es el propio art. 351 del Código Procesal Penal el que tiende precisamente a -como se le reprocha al sistema de acumulación material, problema que se supone evitaría la regla de reiteración- igualar valoraciones diversas (más bien, intuitivamente diversas): adoptando el mismo ejemplo del autor, conforme al régimen de reiteración varios delitos de hurto pueden tener asignada la misma pena en abstracto que el delito de homicidio simple, si se trata de bienes hurtados de más de cuatrocientas UTM y por su número el tribunal decide aumentar dos grados; $\mathrm{u}$-otro ejemplo inversotres delitos reiterados de infanticidio tienen la misma pena abstracta que un delito de homicidio simple; o, en fin, dos delitos reiterados de receptación de cosas que forman parte de un suministro domiciliario de electricidad tienen asignada la misma pena que un solo delito de lesiones graves gravísimas. Por otra parte, es discutible que la reiteración no suponga un aumento significativo de la lesión del bien jurídico adscrito a la pluralidad delictiva: ¿acaso la repetición sucesiva de cuatro homicidios -cuatro muertes de personas diferentes- no significa una lesión significativamente mayor del bien jurídico vida que la afectación asociada a la ejecución de un solo delito de homicidio - una muerte? La idea de humanidad de las penas pareciera explicar mejor el régimen atenuando del sistema de reiteración, sin perjuicio de que el debate, por cierto, queda abierto.

${ }^{5}$ Infra, 2.2.

${ }^{6}$ El carácter imperativo del aumento en al menos un grado, siendo discrecional -conforme al baremo del número de los delitos que integran la reiteración- el incremento en un segundo grado, todo ello respecto tanto del inciso primero como del inciso segundo del art. 351 del Código Procesal Penal, no es discutido a nivel doctrinal ni tampoco jurisprudencial, así -entre otros- Politoff/Matus/Ramírez (POLITOFF, Sergio; MATUS, Jean Pierre; RAMÍREZ, M. Cecilia, Lecciones de Derecho Penal chileno, parte general, Santiago: Ed. Jurídica, 2011, p. 467 [cit.: Lecciones]); al margen de los problemas que presenta en la práctica determinar objetivamente qué número de delitos (a partir de qué número) tiene la eficacia de posibilitar el aumento de carácter facultativo; infra 2.4 . 


\section{Polít. crim. Vol. 10, № 20 (Diciembre 2015), Art. 5, pp. 543-596. \\ [http://www.politicacriminal.cl/Vol_10/n_20/Vol10N20A5.pdf]}

suponen alteraciones relevantes de penalidad, con respecto a dicho incremento en grado (o grados).

Se trata de problemas diferentes, con particularidades y dificultades propias, pero emparentados en algunas de sus consecuencias prácticas.

El primero -la técnica normativamente correcta de realizar el aumento en grado- constituye una cuestión transversal al sistema de determinación de la pena, que se presenta en aquellos supuestos de marcos penales compuestos por dos o más grados de pena cuando una disposición legal obliga o faculta al tribunal a efectuar un aumento en grado sin establecer expresamente desde qué grado de penalidad, de entre aquellos que integran dicho marco penal, debe realizarse el incremento. El problema se verifica, en definitiva, en escenarios no reglados ${ }^{7}$, como ocurre precisamente en el caso del art. 351 del Código Procesal Penal, por contraposición a los supuestos en que el legislador expresamente se ha pronunciado al respecto, como -ejemplo paradigmático- el supuesto del art. $68.4^{\circ}$ del Código Penal (dos o más circunstancias agravantes sin presencia de atenuantes), que contiene una disposición específica que faculta al tribunal a materializar el aumento a partir del grado máximo o, en el mismo sentido, el caso del art. 447 del Código Penal ${ }^{8}$, respecto de la presencia de circunstancias agravantes especiales para el delito de hurto.

El segundo problema es propio de la regla de reiteración de delitos de una misma especie y consiste en la determinación del momento u orden temporal en que deben producir sus efectos sobre el marco penal las circunstancias modificatorias concurrentes, a saber, antes o después del aumento en grado prescrito por el sistema de acumulación jurídica. Dicho problema se genera porque sólo existe una regla explícita al efecto para el caso del inciso segundo del art. 351 del Código Procesal Penal, esto es, para aquellas infracciones que conforme a su naturaleza no pueden ser estimadas como un solo delito, escenario en el cual deben producir sus efectos primero las circunstancias concurrentes, pues el cálculo de pena se realiza -por expreso mandato legal- sobre la base del delito que aisladamente con las circunstancias del caso tenga asignada una pena mayor (pena mayor y delito base para el cálculo que se determina considerando las circunstancias que se presenten), para luego

\footnotetext{
${ }^{7}$ Así, CURY URZÚA, Enrique, Derecho Penal, parte general, $10^{\circ}$ ed., Santiago: Ed. Universidad Católica de Chile, 2011, pp. 762-763 [cit.: Derecho penal]; GARRIDO MONTT, Mario, Derecho Penal, parte general, t. I., $2^{\circ}$ ed., Santiago: Ed. Jurídica, 2005, pp. 319-320 [cit.: Derecho penal]; COUSO SALAS, Jaime, "Comentario previo a los Arts. 50 a 69 y 76 a 78. El sistema de determinación de penas en el derecho chileno", en: COUSO, Jaime; HERNÁNDEZ, Héctor (Dirs.), Código Penal comentado, parte general. Doctrina y jurisprudencia, Santiago: Ed. AbeledoPerrot, 2011, pp. 510-544, pp. 521-522 [cit.: “Comentario previo"].

${ }^{8}$ Si bien el texto del art. 447 del Código Penal no presenta la misma claridad que el art. 68.4 ("podrá imponer la inmediatamente superior en grado al máximo"), en la medida de que no prevé explícitamente que el aumento se realiza a partir del grado máximo ("podrá aplicarse la pena inmediatamente superior en grado"), debe -sin duda- interpretarse en ese sentido, en consistencia con la estructura semántica del precepto, toda vez que de no entenderse así la expresión "inmediatamente superior en grado" carecería de todo sentido y devendría, entonces, en superflua - una redundancia, a fin de cuentas-, en la medida de que los aumentos de grado se realizan, como es obvio, siempre hacia los grados de pena inmediatamente superiores en la escala gradual respectiva; al margen de que tratándose de marcos compuestos por dos o más penas la forma de arribar mediante el aumento de un grado a -únicamente- la pena inmediatamente superior en grado es a través del incremento desde el máximo.
} 


\section{BESIO, Martín. “Aplicación del artículo 351 del Código Procesal Penal”.}

proceder al aumento respectivo. Pero -y he aquí el origen del problema- nada se prevé para las infracciones incluidas al alero del inciso primero, esto es, para aquellas que (a contrario sensu, conforme a su naturaleza) sí pueden ser estimadas como un solo delito.

Se genera, entonces, la pregunta de si en el caso de estas últimas infracciones -las del inciso primero- las circunstancias modificatorias deben producir sus efectos con antelación o con posterioridad al incremento en grado (o grados) propio de la reiteración y, en definitiva, de si el art. 351 del Código Procesal Penal alberga dos sistemas diferentes de cuantificación de la pena para delitos de una misma especie, modelo de cuantificación que en la afirmativa dependerá de la inclusión normativa de los ilícitos en su inciso primero o en su inciso segundo; esto es, dependiendo de si conforme a la naturaleza de las infracciones que integran la reiteración éstas pueden (o no) ser estimadas como un solo delito, decisión subordinada a disímiles interpretaciones por parte de la doctrina y -en la práctica- a un vacío argumental casi absoluto por parte de la jurisprudencia, sin perjuicio de la constatación de algunas tendencias al respecto.

En suma, si se entiende que el art. 351 del Código Procesal Penal contiene una dualidad de sistemas de individualización de la pena -disímiles para su inciso primero y segundoadquiere, en ese entonces, especial importancia dilucidar qué infracciones se integran a cada cual; y, por ello, bajo qué condiciones ilícitos de una misma especie -que afectan al mismo bien jurídico- pueden o no ser estimados como un solo delito.

Ambos problemas se encuentran entrelazados para algunos supuestos en la aplicación del art. 351 del Código Procesal Penal. Si bien ya la sola decisión que se adopte respecto del modo correcto de realizar el aumento en grado conlleva autónomamente a la determinación de penas de diferente intensidad ${ }^{9}$, dicho escenario adquiere un cariz especial, acentuando el dilema, si se aúna a la presencia de circunstancias modificatorias y a la dualidad alternativa sobre el momento -antes o después del incremento- en que éstas producen sus efectos sobre el marco penal. Así, tratándose de infracciones que conforme a su naturaleza pueden ser estimadas como un solo delito (aquellas a que refiere el inciso primero) que tengan asignadas penas compuestas por dos o más grados de penalidad y verificándose la presencia de una pluralidad de circunstancias, el orden de aplicación de los efectos de dichas circunstancias en relación a la técnica que se adopte para la realización del incremento en grado propio de la reiteración conlleva -dependiendo de la forma de aumento- a resultados disímiles, con consecuencias directas para la cuantía de pena resultante.

\footnotetext{
${ }^{9}$ Mientras, como se verá infra, el debate dogmático se ha centrado principalmente sobre dos posibilidades de proceder frente al aumento en grado para los casos no reglados, a saber, a partir del grado máximo o en bloque, sobre ello -entre otros- OLIVER CALDERÓN, "La exasperación”, cit. nota n 2, p. 177, COUSO SALAS, "Comentario previo", cit. nota $\mathrm{n}^{\circ}$ 7, pp. 521-522; la jurisprudencia admite indistintamente tres posibilidades: a partir del grado máximo, en bloque y a partir del grado mínimo (infra, en el texto principal). La relevancia de adoptar una posición al respecto se refleja en las consecuencias que se obtienen desde la óptica de la pena resultante. Así, por ejemplo, frente a un marco penal de presidio menor en sus grados medio a máximo -como el asignado al delito de robo por sorpresa, art. 436 inciso segundo del Código Penal- el aumento de un grado a partir del grado mínimo genera un marco penal de presidio menor en su grado máximo, mientras que si se efectúa en bloque es de presidio menor en su grado máximo a presidio mayor en su grado mínimo, y si se realiza el incremento a partir del grado máximo quedará situado dicho marco penal en presidio mayor en su grado mínimo.
} 


\section{Polít. crim. Vol. 10, № 20 (Diciembre 2015), Art. 5, pp. 543-596. \\ [http://www.politicacriminal.cl/Vol_10/n_20/Vol10N20A5.pdf]}

Una buena aproximación a estas dicotomías punitivas se obtiene -como es obvio y a estas alturas casi obligado para todo análisis sobre determinación de la pena- a través de la jurisprudencia.

En ese contexto, resulta especialmente ilustrativa la sentencia del tribunal oral en lo penal (en adelante, "STOP”) de Santiago, (4) Rit 267-2014, de 15/12/2014, que se pronuncia en el escenario de delitos de la Ley de Mercado de Valores (Ley 18.045). Dicha sentencia -en lo que aquí interesa-condenó a uno de los acusados a la pena de nueve años de presidio mayor en su grado mínimo en calidad de autor de los delitos reiterados de uso indebido de custodia (art. 60.i) y de entrega de información falsa a la Superintendencia de Valores y Seguros (art. 59.a), concurriendo respecto del primer delito reiterado dos atenuantes sin la presencia de agravantes; y tratándose del segundo delito una sola atenuante, también sin agravantes. Respecto del segundo acusado, la sentencia impuso la pena de cinco años de presidio menor en su grado máximo por su intervención en calidad de autor de los delitos reiterados de uso indebido de custodia, con la presencia de una atenuante, sin agravantes.

El razonamiento utilizado por el tribunal para arribar a las penas ya referidas, es -en lo esencial- el siguiente:

"Que el delito de uso indebido de custodia se encuentra previsto y sancionado en el artículo 60 letra i) de la Ley 18.045 con la pena de presidio menor en cualquiera de sus grados, en tanto que el ilícito de entrega maliciosa de información falsa, se halla sancionado en el artículo 59 letra a) de la misma ley, con la pena de presidio menor en su grado medio a presidio mayor en su grado mínimo. Ahora bien, siendo ambos ilícitos de la misma especie por afectar bienes jurídicos idénticos, corresponde imponer la pena a las diversas infracciones estimadas como un solo delito, aumentándola en un grado, es decir, a presidio mayor en su grado medio.

Que beneficiando al acusado Serrano dos atenuantes, corresponde disminuir la pena en un grado, quedando en definitiva en presidio mayor en su grado mínimo.

Que beneficiando al acusado Fuenzalida una atenuante, la pena que corresponde imponerle solo como autor del delito de uso indebido de custodia, no será aplicada en su grado máximo".

Como se advierte, respecto del primer acusado el tribunal asumió el siguiente razonamiento: sobre la base de considerar a ambos ilícitos como delitos de una misma especie - pues se afirma que tutelan bienes jurídicos idénticos- que pueden ser estimados como un solo delito -alusión inequívoca al inciso primero del art. 351 del Código Procesal Penal-, se adoptó como base del cálculo de pena la infracción que tiene asignada una pena mayor (esto es, el delito del art. 59.a de la Ley 18.045: presidio menor en su grado medio a presidio mayor en su grado mínimo), aplicando luego el aumento imperativo de un grado derivado de la reiteración, quedando fijado un marco provisional de presidio mayor en su grado medio. Y dicho marco provisional fue depurado luego por el tribunal a través de los efectos asignados a la presencia de dos circunstancias atenuantes, disminuyendo la pena en un grado, resultando -en definitiva- un marco penal concreto de presidio mayor en su grado mínimo, al interior del cual fijó la cuantía específica de sanción en nueve años. 


\section{BESIO, Martín. “Aplicación del artículo 351 del Código Procesal Penal”.}

De dicho razonamiento de individualización queda de manifiesto que el tribunal adoptó -al menos- tres decisiones relevantes. Por una parte, realizó el aumento de un grado en virtud del art. 351 del Código Procesal Penal desde el grado máximo del marco penal base (de un marco de presidio menor en su grado medio a presidio mayor en su grado mínimo arribó, vía aumento de un grado, a una pena de presidio mayor en su grado medio) ${ }^{10}$. Por otra parte, estimó que ambas infracciones de la misma especie -que presentan penas abstractas y concretas de diferente cuantía- pueden ser estimadas como un solo delito y, por ello, adscritas al inciso primero de dicha regla. Por último, en aplicación del inciso primero del art. 351 del Código Procesal Penal realizó en primer lugar el aumento en grado propio de la reiteración y con posterioridad a dicho incremento aplicó sobre el marco penal los efectos de la pluralidad de atenuantes.

De acuerdo a la sentencia, en definitiva, el art. 351 del Código Procesal Penal contiene dos sistemas diferentes de individualización de la pena para delitos de una misma especie, postura que también se advierte - tácitamente- con cierta frecuencia en la jurisprudencia: mientras que en la operación del inciso primero las atenuantes producen sus efectos con posterioridad al aumento en grado propio de la reiteración, el inciso segundo - dado su texto literal- obliga a que las circunstancias depuren el marco penal con antelación (para los efectos de la determinación del delito con pena mayor) al aumento de grado.

La existencia (o no) de una dualidad de sistemas en la regla de reiteración de delitos de la misma especie no es un problema meramente nominal o teórico, pues en algunos supuestos -como se expondrá infra - tiene consecuencias relevantes desde la óptica de la cuantía de pena $^{11}$; de ahí su relevancia.

\footnotetext{
${ }^{10}$ Aún cuando la sentencia no lo establece expresamente, se infiere de su razonamiento que el marco penal base que utilizó para el cálculo de pena fue el correspondiente al delito con pena mayor, a saber, la pena asignada al delito de entrega de información falsa (presidio menor en su grado medio a presidio mayor en su grado mínimo) y que -además- el aumento de un grado lo realizó a partir del grado máximo de dicho marco (presidio mayor en su grado mínimo), pues considerando el marco resultante del proceso de incremento de un grado por la reiteración (presidio mayor en su grado medio) no resulta posible que haya utilizado como base la pena asignada el delito de uso indebido de custodia (presidio menor en cualquiera de sus grados) y/o que haya utilizado otra forma distinta de aumento en grado. En efecto, si hubiese tomado como base la pena asignada al delito de entrega de información falsa y hubiese realizado el aumento a partir del grado mínimo o en bloque, el marco resultante hubiese sido distinto (presidio menor en su grado máximo, en el primer caso; y presidio menor en su grado máximo a presidio mayor en su grado medio, en el segundo). Lo mismo ocurre en el evento de que hubiese adoptado como delito base el delito de uso indebido de custodia: debería haber arribado a una pena de presidio mayor en su grado mínimo si hubiese realizado el aumento a partir del grado máximo de dicho marco; y a las penas de presidio menor en su grado medio (incremento desde el mínimo) o de presidio menor en su grado medio a presidio mayor en su grado mínimo (incremento en bloque), todas penas diferentes a la que impuso la sentencia (presidio mayor en su grado medio).

11 Ello es evidente si se proyectara el razonamiento de esta sentencia para el caso en que se hubiesen configurado dos atenuantes respecto del delito de entrega de información falsa, pues en ese evento -dado que la disminución en un grado se realiza a partir del grado mínimo- el marco provisional, aplicando primero los efectos derivados de la pluralidad de atenuantes, estaría constituido por presidio menor en su grado mínimo, el que luego del aumento en grado quedaría situado en presidio menor en su grado medio (por contraposición a la pena fijada por la sentencia: presidio mayor en su grado mínimo). No obstante, en este caso, dado la eficacia limitada de depuración del marco penal asignada a la presencia de una sola atenuante (en comparación a los efectos asociados a una pluralidad), una eventual inversión del orden de aplicación de las reglas seguido por la sentencia no hubiese alterado el marco penal resultante, a diferencia de otros supuestos jurisprudenciales; aunque otra cuestión sucede -infra, en el texto principal- si se adoptase otro procedimiento
} 


\section{Polít. crim. Vol. 10, № 20 (Diciembre 2015), Art. 5, pp. 543-596. \\ [http://www.politicacriminal.cl/Vol_10/n_20/Vol10N20A5.pdf]}

Al margen de ello, interesa destacar por ahora, en contraste, el procedimiento seguido por la sentencia respecto del segundo acusado (condenado a la pena de cinco años de presidio menor en su grado máximo en razón del delito reiterado de uso indebido de custodia, con la presencia de una atenuante), dado que a su respecto -sin justificarlo- el tribunal adoptó un sistema distinto de aumento de grado en razón de la exasperación. En efecto, sobre la base de un marco penal de presidio menor en cualquiera de sus grados -marco penal compuesto por tres penas divisibles asignado al delito de uso indebido de custodia- realizó el aumento de un grado en bloque ${ }^{12}$ (aumentando en un grado cada uno de los grados de pena contenidos en el marco original), situando provisionalmente la pena en presidio menor en su grado medio a presidio mayor en su grado mínimo, para luego -por efecto de la aplicación de la atenuante concurrente- excluir el grado máximo de dicho marco ("no será aplicada en su grado máximo"), quedando fijado entonces el marco concreto en presidio menor en sus grados medio a máximo, dentro del cual impuso la pena en su límite superior (cinco años).

Se advertirá que si el tribunal hubiese realizado el aumento en grado a partir del grado máximo, como lo hizo respecto del primer acusado, la pena objeto de la condena del segundo debió ser ostensiblemente mayor a la impuesta, a saber, al interior del mínimum de presidio mayor en su grado mínimo. Y si hubiese aumentado un grado desde el grado mínimo -técnica que suele adoptar buena parte de la jurisprudencia- el resultado hubiese sido también diferente: una pena de presidio menor en su grado medio, en su mínimum.

En definitiva, varias posibilidades de pena dependiendo de la forma que adopte el aumento de grado propio de la reiteración; y dos sistemas diferentes de incremento -a partir del grado máximo y en bloque- en aplicación de una misma regla, utilizados por una misma sentencia.

Las diferencias punitivas que presenta en la práctica la aplicación del art. 351 del Código Procesal Penal quedan también de manifiesto al comparar la anterior sentencia -y su razonamiento soporte de la determinación de la pena- con una providencia dictada por el mismo tribunal tan sólo dos meses antes.

de aumento en grado. Si el tribunal hubiese seguido el sistema ordenado por el inciso segundo (el que se entiende como correcto toda vez que ambas infracciones tienen asignadas penas abstractas y -especialmentepenas concretas distintas; infra), debió haber tomado como base para el cálculo de pena el delito de entrega de información falsa (marco penal: presidio menor en su grado medio a presidio mayor en su grado mínimo), aplicando a su respecto la circunstancia atenuante concurrente y construyendo entonces un marco penal provisional de presidio menor en sus grados medio a máximo, respecto del cual debió luego haber realizado el aumento en grado -como lo hizo la sentencia- a partir del grado máximo, resultando situado el marco penal concreto en presidio mayor en su grado mínimo.

${ }^{12}$ Otra posibilidad - no explicitada en la sentencia- para arribar al mismo resultado en este caso, consiste en que el tribunal hubiese invertido el orden de aplicación utilizado respecto del primer acusado y, por tanto, hubiese aplicado primero los efectos de la atenuante, situando el marco provisional en presidio menor en sus grados mínimo a medio, para luego realizar el aumento a partir del grado máximo. Si bien ello resultaría también contradictorio, pues también revelaría la adopción de un orden de aplicación de reglas distinto para cada uno de los acusados, no parece condecirse con el orden y estructura argumental que contiene la sentencia (primero se refiere al aumento y luego a los efectos de la atenuante) ni -especialmente- resulta consistente con la expresión "no será aplicada en su grado máximo" asociada al efecto de la atenuante sobre la pena, que resulta acorde con la aplicación de ésta con posterioridad al aumento en grado propio de la reiteración. 
BESIO, Martín. “Aplicación del artículo 351 del Código Procesal Penal”.

La STOP Santiago $\left(4^{\circ}\right)$ Rit 454-2014, de 22/10/2014, sentenció a uno de los acusados a la pena de cinco años y un día de presidio mayor en su grado mínimo como autor de dos delitos reiterados de robo con intimidación (art. $436 \mathrm{CP}$ ) -uno tentado y otro consumado-, concurriendo respecto de ambos ilícitos dos circunstancias atenuantes, sin presencia de agravantes. El razonamiento de determinación de la pena -en lo esencial- es el siguiente:

“2.1.- La pena base del delito de robo con intimidación es la de presidio mayor en sus grados mínimo a máximo.

2.2.- Concurren en la especie las siguientes modificatorias: $11 \mathrm{~N}^{\circ} 6$ del Código Penal, irreprochable conducta anterior, con el mérito de su extracto de filiación y antecedentes exento de anotaciones pretéritas, y $11 \mathrm{~N}^{\circ} 9$ del Código Penal, cooperación sustancial al esclarecimiento de los hechos.

Que, consecuencialmente -en el caso de marras se han establecido- 02 atenuantes y ninguna agravante.

2.3.- Que al respecto este acusado participó en los hechos numerados 1 y numerados 2 , consecuencialmente según lo dispuesto en el art. 351 del Código Procesal Penal, y tratándose de una reiteración de delitos de una misma especie, primariamente estos sentenciadores aumentarán la pena del bloque de inicio de la pena en un grado, comenzando ésta en presidio mayor en su grado máximo.

2.5.- Como paso siguiente y concurriendo en la especie dos atenuantes según lo dispuesto en el artículo 68 del Código Penal, este tribunal, atento a las circunstancias del delito, rebajará en un grado al de la pena signada por el delito (...). Así las cosas, ésta quedará nuevamente en el tramo de presidio mayor en su grado mínimo. Pudiendo estos jueces recorrer toda la extensión del bloque señalado, y atentos a las circunstancias del caso de marras aplicarán la pena en el mínimo del grado según se expresará en la parte resolutiva de la sentencia”.

De dicha línea argumental se desprende que la sentencia estimó como de una misma especie (aunque sin determinar explícitamente si al alero del inciso primero o segundo de la regla de reiteración) dos delitos de robo con violencia, por lo que en aplicación del art. 351 del Código Procesal Penal aumentó primero en un grado la -que denomina como- "pena base" de dicho ilícito, para luego proceder a la disminución de un grado como consecuencia de los efectos que asignó a la pluralidad de atenuantes concurrentes. Aun cuando se alude como marco penal primario del procedimiento de cuantificación a la pena base del delito de robo con intimidación, expresión que podría entenderse como una referencia al marco abstracto asignado por ley a dicho ilícito, en este caso, dado que los delitos presentan diferentes fases de ejecución - uno tentado y otro consumado- la expresión debe entenderse como alusiva al marco penal del delito consumado.

Una primera cuestión a destacar -y en esto existe coincidencia con el procedimiento seguido por la anterior sentencia del mismo tribunal- es el orden de aplicación de las reglas concurrentes: primero el aumento en grado impuesto por la exasperación y posteriormente la rebaja en un grado en razón de las dos atenuantes; de lo que se infiere que el tribunal estimó que ambas infracciones - una tentada y la otra consumada- pueden ser estimadas como un solo delito y, por tanto, adscritas al inciso primero del sistema de acumulación jurídica (toda vez que el inciso segundo prevé un orden inverso de producción de los efectos de ambas hipótesis de depuración del marco penal). 
De nuevo, el reconocimiento tácito de dos sistemas diferentes de cuantificación que conviven al interior del art. 351 del Código Procesal Penal ${ }^{13}$.

La sentencia, además -pese a un error de redacción que dificulta la inteligencia del procedimiento adoptado- realizó el incremento en grado derivado de la reiteración en bloque (y no a partir del grado máximo). Así se infiere del razonamiento expuesto: el tribunal adopta como base del cálculo la pena de presidio mayor en sus grados mínimo a máximo, a partir de la cual aumentó un grado en bloque ("aumentarán la pena del bloque de inicio de la pena en un grado, comenzando ésta en presidio mayor en su grado máximo”, debiendo decir -y aquí está el yerro- "comenzando ésta en presidio mayor en su grado medio"), quedando el marco pena provisional constituido por presidio mayor en su grado medio a presidio perpetuo simple; y luego -por efecto de las dos atenuantes concurrentesdisminuyó en un grado dicho marco a partir de su grado mínimo (como dispone el art. 68 del Código Penal, a saber, a partir de presidio mayor en su grado medio), situando el marco concreto en la pena de presidio mayor en su grado mínimo (esto es: por efectos de la pluralidad de atenuantes "ésta quedará nuevamente en el tramo de presidio mayor en su grado mínimo").

Lo relevante de constatar - por ahora- es la dualidad de modelos de aumento en grado que adopta la jurisprudencia en aplicación del art. 351 del Código Procesal Penal. Mientras la primera sentencia analizada utiliza tanto el aumento a partir del grado máximo como el aumento en bloque (una técnica diferente para cada acusado), la segunda se inclina por el segundo procedimiento; y -como se verá infra- otra tendencia jurisprudencial asume el aumento a partir del grado mínimo. La cuestión, como es obvio, no es baladí, pues repercute de forma directa en la decisión de condena. Basta con proyectar que si en el caso de esta segunda sentencia el tribunal hubiese realizado - tal y como la primera- el aumento en grado desde el grado máximo de pena, ésta debió imponerse (siguiendo el mismo orden de aplicación del aumento versus las atenuantes) al interior de un marco de presidio mayor en su grado máximo, pena distinta -diametralmente distinta- a la de presidio mayor en su grado mínimo fijada por la sentencia.

Asimismo, las diferentes consecuencias asociadas al orden en que se otorga eficacia al aumento en grado derivado de la reiteración en relación a los efectos sobre el marco penal propio de las circunstancias concurrentes, se refleja con meridiana claridad a partir de una proyección alternativa de cuantificación asociada a este supuesto. En efecto, si el tribunal hubiese realizado el aumento en grado a partir del grado máximo -tal y como procedió la primera sentencia respecto del primer acusado, procedimiento que la doctrina suele advertir como la posición mayoritaria de la jurisprudencia ${ }^{14}$ - pero otorgando preferencia a los efectos de las atenuantes por sobre el incremento derivado de la exasperación -esto es, invirtiendo el orden de su concurrencia-, la pena habría sido impuesta al interior de un

\footnotetext{
${ }^{13}$ El reconocimiento de esta dualidad de sistemas de individualización al interior del art. 351 del Código Procesal Penal para infracciones de una misma especie, se advierte también en las decisiones de tribunales superiores; paradigmática al respecto -en razón del mayor despliegue argumental que contiene- la SCS Rol 7224-2013, de 11/11/2013, infra, en el texto principal.

${ }^{14}$ MATUS ACUÑA, Jean Pierre, “Artículo 77”, en: POLITOFF, Sergio; ORTIZ, Luis (Dirs.), Texto y Comentario del Código Penal chileno, t. I, Santiago: Ed. Jurídica, 2002, pp. 403-407, p. 404 [cit.: “Artículo”].
} 
BESIO, Martín. “Aplicación del artículo 351 del Código Procesal Penal”.

marco penal de presidio mayor en su grado mínimo, a diferencia de la pena de presidio mayor en su grado máximo resultante -como ya se expuso- del aumento a partir del grado máximo en conexión con la aplicación preferente de dicho incremento con respecto a los efectos de las atenuantes.

Una última cuestión a resaltar radica en el régimen de subsidiariedad existente entre la operatoria del sistema de acumulación jurídica y el sistema general de acumulación material del art. 74 del Código Penal, régimen condicionado normativamente por la posibilidad - en la comparación del resultado punitivo derivado de ambos por separado- de imposición de una pena menor. La sentencia no desarrolla ningún tipo de análisis al respecto, dando por sentada la aplicación del art. 351 del Código Procesal Penal a través de la generación de una pena única, en circunstancias que la determinación de la pena de ambos delitos por separado, pese a que cuantitativamente -si se sumasen sus extensiones temporales- genera una pena de mayor duración que la sanción resultante del sistema de reiteración de delitos de una misma especie, desde un punto de vista cualitativo, considerando la clase de sanción aplicable individualmente, podría implicar eventualmente- una pena menor.

El escenario de comparación es simple: una pena única -conforme al régimen de reiteración- de cinco años y un día de presidio mayor en su grado mínimo (que corresponde a la pena impuesta, no susceptible de sustitutivo penal), versus dos penas inferiores a cinco años (si se sigue el mismo razonamiento estructural de la sentencia: una pena de presidio menor en su grado máximo en razón del delito consumado y otra pena de presidio menor en su grado mínimo asociada al delito tentado), ambas susceptibles por separado -si es que se admite esa posibilidad- de conversión en penas sustitutivas. La pregunta clave, en este escenario, es cuál de dichas posibilidades constituye normativamente una pena menor ${ }^{15}$.

En contraste con las providencias referidas, la STOP Santiago $\left(1^{\circ}\right)$ Rit $17-2014$, de 05/01/2015, utiliza en la aplicación del art. 351 del Código Procesal Penal un orden diferente de convergencia de los efectos del aumento en grado propio de la exasperación y de los efectos de las circunstancias concurrentes. Dicha providencia, respecto de la comisión de tres delitos consumados del art. 22 del DL 2460, cuyo marco penal abstracto por remisión al art. 206 del Código Penal- es de presidio menor en sus grados medio a máximo, con la presencia de dos atenuantes, impuso a uno de los condenados la pena de tres años de presidio menor en su grado medio, a través del siguiente razonamiento central:

“(...) siendo la pena asignada al ilícito la del artículo 206 del Código Penal, habiendo sido sancionado el justiciable Borneck Gutiérrez por tres de estos delitos en calidad de autor, encontrándose ellos en grado consumado y teniendo presente que le beneficia en cada uno las atenuantes del artículo $11 \mathrm{~N}^{\circ} 6$ y 9 del Código Penal y no perjudicándole agravante alguna, el Tribunal procederá a hacer uso de la facultad contemplada en el inciso cuarto del artículo 68 del citado cuerpo legal, rebajando en un grado la sanción aplicable en la especie, quedando ésta en el umbral del presidio menor en su grado mínimo, la que se impondrá en el límite superior del rango punitivo indicado para cada una de ellas, habida consideración de la mayor extensión del mal causado por el obrar del acusado (...).

${ }^{15}$ Infra, 2.5. 
Ahora bien, teniendo presente que se está en presencia de una reiteración de delitos, las sanciones correspondientes a las tres infracciones se impondrán al tenor de lo preceptuado en el artículo 351 del Código Procesal Penal -una pena de 3 años-, por ser esta forma de interpretación, más beneficiosa en este caso que la del artículo 74 del Código Penal, que de aplicarse arrojaría una extensión punitiva, desde un prisma cuantitativo, superior a la indicada, lo que ratifica la decisión adoptada en este sentido, conforme pasará a reseñarse en la resolutiva".

El procedimiento de cuantificación utilizado por la sentencia respecto de tres delitos reiterados que -individualmente considerados- tienen asignada la misma pena tanto en abstracto como en concreto, aun cuando no se refiere al alero de qué inciso de la regla de exasperación opera, consistió en otorgar una aplicación preferente sobre el marco penal a los efectos de las atenuantes concurrentes por sobre el aumento en grado propio de la reiteración. Así, tomando como referencia la pena base de presidio menor en sus grados medio a máximo, redujo dicho marco en un grado desde el mínimo (como es obligado) en razón de las atenuantes, situándose el marco provisional en presidio menor en su grado mínimo, el que - a continuación- producto del aumento en grado derivado de la regla de exasperación se concretó en presidio menor en su grado medio, dentro del que se impuso la cuantía de pena definitiva (tres años).

Se advertirá que el orden de preferencia asignado por la sentencia influyó de modo determinante en la pena impuesta, pues de haberlo invertido (aplicando primero el aumento derivado de la exasperación y posteriormente los efectos de las atenuantes), tal y como procedieron las sentencias reseñadas supra, el resultado punitivo podría eventualmente dependiendo de la forma que adopte el aumento- haber sido distinto. Así, de haberse realizado primero el aumento en un grado (dando eficacia posterior a las atenuantes) y desde el grado máximo, la pena hubiese sido fijada al interior de un marco concreto de presidio menor en su grado máximo, no existiendo diferencias en el supuesto de verificación del aumento en bloque o a partir del grado mínimo.

No sólo la forma que adopte el aumento en grado propio de la exasperación resulta relevante; sino que también -y en conexión con éste- el orden en que se otorga eficacia a las reglas que inciden en la depuración del marco penal asociado a la reiteración.

\subsection{Aumentos de grado en escenarios no reglados.}

Tratándose de marcos penales compuestos por dos o más grados de pena, susceptibles de modulación a través de una regla que obliga o -en su caso- permite realizar un incremento en grado sin establecer expresamente desde qué grado de pena de aquellos que integran el marco penal debe realizarse dicho aumento; en ese escenario problemático -generado por la ausencia de una definición explícita del legislador- la jurisprudencia opera indistintamente a través de cada una de las alternativas teóricas posibles, a saber, realizando el incremento a partir del grado mínimo, a partir del grado máximo y también en bloque (esto es, aumentando en el número de grados respectivo y a través de la escala gradual respectiva 


\title{
BESIO, Martín. “Aplicación del artículo 351 del Código Procesal Penal”.
}

cada una de las penas contenidas en el marco penal base del aumento, generándose así un marco penal superior compuesto por el mismo número de penas que el primario) ${ }^{16}$.

En las decisiones de condena la opción por uno u otro procedimiento no se encuentra como regla general- precedida del debido soporte argumental que justifica la elección; se trata más bien de una práctica judicial constante que -sin advertir el problema y sus consecuencias- se asume tácitamente en cada sentencia y de la que se desconoce -pues no se explicita- su fundamento. Tampoco es posible aseverar con un grado razonable de certeza cuál es la tendencia mayoritaria, dado el alto y creciente número de fallos y -por ahora- la ausencia del debido sustento empírico que otorgue a una de dichas opciones tal categoría, aun cuando es posible constatar la existencia de una línea jurisprudencial relevante que asume el aumento en grado a partir del grado mínimo ${ }^{17}$.

Así, la sentencia de la Corte de Apelaciones (en adelante, "SCA") de San Miguel Rol 155/2012, de 26/03/2012, al interior del análisis sobre la aplicación preferente del art. 74 del Código Penal con respecto al art. 351 del Código Procesal Penal, sostiene expresamente que el incremento en grado debe realizarse desde el grado máximo (o "tramo superior de la pena") en aplicación de esta última regla:

\begin{abstract}
"Que estos sentenciadores, realizando el ejercicio hipotético pertinente de la sanción que resultaría más beneficiosa para el condenado, han concluido que en los dos casos que refiere el artículo 351 en sus incisos primero y segundo, la aplicación del castigo como autor de tres homicidios, uno de ellos con una agravante y un delito de tenencia de arma de fuego, resulta una pena superior a la que en definitiva aplicó el tribunal del juicio oral, pudiendo llegar hasta la pena de presidio perpetuo simple, esto quiere decir que se comparte la opción de aplicar el artículo 74 del Código Penal, que contempla el inciso tercero del citado artículo 351 del Código Procesal Penal, más aún cuando los aumentos de dos grados se debe realizar desde el tramo superior de la pena que establece la ley para el delito; de otra manera resultaría intrascendente la multiplicidad de delitos para los efectos de aplicar las sanciones corporales".
\end{abstract}

\footnotetext{
${ }^{16} \mathrm{El}$ problema se produce en ese escenario y sólo respecto de la forma que adopta el aumento en grado, toda vez que tratándose de las disminuciones de grado el legislador, para casi todos los supuestos, prevé expresamente que éstas se realizan a partir del grado mínimo; así, entre otros, los arts. $61.2^{\circ}, 66$ inciso tercero, 68 inciso tercero, 68 bis y 73, todos del Código Penal, destacando COUSO SALAS, "Comentario previo", cit. nota $\mathrm{n}^{\circ} 7$, p. 521, que "(...) para los casos en que ello no está expresamente resuelto (un ejemplo: la regla del Art. $1^{\circ}$, inc. $2^{\circ}$, de la Ley 20.000 , que permite rebajar la pena en un grado para el tráfico de drogas que no produzcan efectos tóxicos o dañinos para la salud) la doctrina aplica la misma solución”, solución -para aquellos casos no reglados- correcta, en la medida que constituye una interpretación sistemática consistente de la ley penal, en beneficio -además- del condenado. De todas formas, es posible advertir algunas sentencias (excepcionales, con todo) que adoptan otros procedimientos de disminución de grado, incluso contra el texto expreso de la ley, como - por ejemplo, entre otras- la sentencia de la Corte Suprema Rol 5213-2009, de 21/10/2009, que tratándose de la rebaja imperativa de un grado asociada a la frustración de un delito de parricidio, disminución que el art. $61.2^{\circ}$ del Código Penal ordena explícitamente que se realiza desde del grado mínimo (“corresponde la inmediatamente inferior en grado al mínimo"), la Corte Suprema lo efectúa en bloque, esto es, disminuyendo en un grado cada uno de los grados de penalidad del marco penal primario: " $[\mathrm{e}] \mathrm{n}$ efecto, el delito de parricidio tiene asignada pena de presidio mayor en su grado máximo a presidio perpetuo calificado. Atendido el grado de desarrollo del delito, ese tramo ha de rebajarse en un grado, quedando entonces en presidio mayor en su grado medio a presidio perpetuo simple".

${ }^{17}$ En contra, como se expuso, MATUS ACUÑA, "Artículo", cit. nota n ${ }^{\circ} 14$, p. 404, quien entiende que "(...) la jurisprudencia tiende a aplicar el aumento desde el grado máximo".
} 


\section{Polít. crim. Vol. 10, № 20 (Diciembre 2015), Art. 5, pp. 543-596. \\ [http://www.politicacriminal.cl/Vol_10/n_20/Vol10N20A5.pdf]}

También, recientemente, la STOP Valparaíso Rit 510-2014, de 30/01/2015, decide realizar el aumento desde el grado máximo, tratándose de delitos reiterados de homicidio simple, sin circunstancias modificatorias:

"La pena principal del delito de homicidio simple es de presidio mayor en sus grados mínimo a medio, esto es, dos grados de una divisible y no existiendo circunstancias modificatorias de responsabilidad criminal que considerar, el Tribunal puede recorrer toda su extensión.

(...) aplicando la regla del delito reiterado del artículo 351 inciso primero del Código Procesal Penal, debe imponerse la pena correspondiente a las diversas infracciones estimadas como un solo delito, aumentándola en uno o dos grados. En este caso, el Tribunal aumentará la pena del delito en un grado, quedando en presidio mayor en su grado máximo, fijándola en veinte (20) años, por las mismas razones ya expresadas más atrás, lo que es más beneficioso para el acusado que aplicar el artículo 74 del Código Penal".

Por contra, la SCA Santiago Rol 1418-2010, de 07/09/2010, sostiene explícitamente que el incremento se realiza a partir del grado mínimo, tratándose de delitos reiterados de fraude al fisco:

"Que para efectos de la intensidad del castigo que debe imponerse es preciso hacer constar que la pena asignada a los delitos de fraude al Fisco es la de presidio menor en su grado medio a máximo; y la contemplada para los de uso malicioso de instrumento privado mercantil falso es la de presidio menor en su grado máximo. En ambos casos, separadamente, la sanción se elevará en un grado por tratarse de reiteración de delitos de una misma especie.

Resulta fijada así cada sanción, respectivamente, en presidio menor en grado máximo (tratándose de los delitos de fraude, en los cuales la elevación de pena se efectúa a partir del mínimo) y presidio mayor en su grado mínimo (en los delitos de uso malicioso)".

La SCA Santiago Rol 2327-2010, de 17/12/2010, valida como correcto el aumento de un grado realizado a partir del grado mínimo por parte de la sentencia recurrida; a través del siguiente razonamiento:

"Que en el considerando vigésimo del fallo recurrido, el tribunal señala acertadamente que la pena correspondiente al delito de robo con intimidación es presidio mayor en grado mínimo a máximo. En virtud de la reiteración, al aplicar la sanción, el tribunal la calculó desde el grado mínimo y la aumentó en un grado dejándosela en definitiva en presidio mayor en su grado medio, lo que se ajusta plenamente a lo que dispone el artículo 351 del Código Procesal Penal para los casos de reiteración de crímenes o simples delitos de la misma especie. Dicho precepto expresa que en tales casos, se impondrá la pena correspondiente a las diversas infracciones estimadas como un solo delito aumentándolo en uno o dos grados, que es lo que precisamente se hace en la sentencia impugnada". 
BESIO, Martín. "Aplicación del artículo 351 del Código Procesal Penal”.

También, la SCA San Miguel Rol 200-2010, de 27/04/2011, en materia de delitos tributarios reiterados:

"Que la conducta descrita en el artículo $97 \mathrm{~N}^{\circ} 4$ inciso final del Código Tributario, es sancionada con la pena de presidio menor en sus grados medio a máximo y, aplicando las reglas establecidas en el artículo 351 del Código Procesal Penal, debe imponerse la pena correspondiente a las diversas infracciones, estimadas como un solo delito, aumentándola en uno o dos grados, la que en este caso se incrementará en sólo un grado, quedando finalmente en la de presidio menor en su grado máximo, el que se regulará en su mínimum, atendida la circunstancia atenuante de responsabilidad de irreprochable conducta anterior que beneficia al encausado".

En la misma línea se pronuncia la STOP Cañete Rit 89-2014, de 17/12/2014, en el contexto de delitos reiterados de violación del art. 362 del Código Penal:

"Que en cuanto a la pena asignada al delito de violación de menor de 14 años en virtud de lo señalado en el artículo 362 del Código Penal, la pena aplicable es la de presidio mayor en cualquiera de sus grados, esto es, de 5 años y un día a 20 años. Así considerando que se trata de delitos reiterados de la misma especie es que por aplicación de lo dispuesto en el artículo 351 inciso primero del Código Procesal Penal, se aplicarán las penas considerándolas como un solo delito aumentándola en un grado, subiendo en consecuencia el mínimo a 10 años y un día".

En el mismo sentido, la STOP Los Ángeles Rit 54-2014, de 09/06/2014, en el escenario de un delito reiterado de homicidio simple -conforme a su anterior sanción de presidio mayor en sus grados mínimo a medio- procedió al aumento en un grado derivado de la exasperación a partir del grado mínimo:

"Que, al hacer aplicación de lo dispuesto en la regla contenida en el inciso $1^{\circ}$ del artículo 351 del Código Procesal Penal, debe imponerse la pena correspondiente a las diversas infracciones estimadas como un solo delito, aumentándola en uno o dos grados.

Pues bien, la pena mínima es la de presidio mayor en su grado mínimo, y por tratarse de dos delitos, el Tribunal estima proporcionado aumentarla en un solo grado, quedando ésta en presidio mayor en su grado medio, cuyo rango va desde diez años y un día a quince años; y existiendo a su favor una circunstancia atenuante $\left(11 \mathrm{~N}^{\circ} 6\right)$ y ninguna agravante, cobra aplicación lo dispuesto en el artículo 67 del Código Penal, esto es, que debe imponerse en su mínimum".

También la STOP Calama Rit 86-2014, de 18/06/2014, opera a través del aumento a partir del grado mínimo tratándose de delitos reiterados de amenazas condicionales:

"Que, constando que al encausado Juan Bautista Ríos Flores, no le perjudican circunstancias agravantes de responsabilidad penal y si le beneficia una circunstancia atenuante de irreprochable conducta anterior, se estima que este Tribunal se encuentra en la hipótesis establecida en el inciso 2 del artículo 68 del Código Penal, el cual establece que el tribunal «no podrá» aplicar el grado máximo de los designados por ley. 


\section{Polít. crim. Vol. 10, № 20 (Diciembre 2015), Art. 5, pp. 543-596. \\ [http://www.politicacriminal.cl/Vol_10/n_20/Vol10N20A5.pdf]}

En el caso del delito de amenazas condicionadas contemplado en el artículo $296 \mathrm{~N}^{\circ} 2$ del Código Penal, el marco penal abstracto es de presidio menor en sus grados mínimo a medio. Dado que se ha tenido por establecido que se trata de delitos consumados reiterados, procede elevar la pena a presidio menor en su grado medio, y allí aplicarla en su mínimum, según dispone el artículo 67, inciso 2, del código punitivo, esto es, entre 541 y 817 días de presidio menor en grado medio".

La STOP Santiago ( $3^{\circ}$ ) Rit 159-2014, de 11/10/2014, en el marco de delitos reiterados de abuso sexual del art. 366 bis del Código Penal (cuyo marco penal asociado es de presidio menor en su grado máximo a presidio mayor en su grado mínimo), decide que el aumento en grado derivado de la exasperación se realiza desde el grado mínimo; en los siguiente términos:

"Que por esto respecto de los delitos reiterados de abuso sexual del artículo 366 bis del Código Penal en grado de desarrollo de consumado (...) una vez aumentado en un grado la pena como dispone el artículo 351 del Código Penal, la pena queda situada en la de presidio mayor en su grado mínimo.

Que dentro de los límites del grado referido, concurriendo una atenuante del número $\mathrm{N}^{\mathrm{o}} 6$ del artículo 11 del Código Penal y no concurriendo otras circunstancias modificatorias, se deberá rebajar en un grado como dispone el artículo 68 bis del Código Penal, y quedando de esta forma en una pena de presidio menor en su grado máximo, y concurriendo la circunstancia de inciso $1^{\circ}$ del artículo 368 del Código Penal, no se podrá imponer en su mitad inferior".

La STOP Santiago (5) Rit 210-2014, de 30/12/2014, decide también realizar el aumento en grado desde el grado mínimo del marco penal base:

"Para ambos encartados y considerando que la UTM a la fecha de los hechos fluctúa entre los $\$ 36.000$ y hasta los $\$ 40.000$, entre los años 2007 y 2011, las sumas defraudadas individualmente consideradas, los sitúan en los numerales $2^{\circ}$ y $3^{\circ}$ del artículo 467 del Código Penal, sin embargo, la determinación así formulada, los lleva a la imposición de dos penas, una de presidio menor en su grado mínimo y otra de presidio menor en su grado medio, ambas reiteradas en cada caso, es decir, debidamente aumentadas en un grado, se traducen en una pena de quinientos cuarenta y un días y otra de tres años y un día, interpretación que no favorece a los encartados para quienes, la suma de sus defraudaciones los deja comprendidos en el supuesto del numeral primero, que integra dos grados de una divisible, concretamente presidio menor en su grado medio a máximo, que aumentadas en un grado por reiteración, determina para ambos por concepto de fraude de subvenciones la pena única de tres años y un día en el mínimo, lo que expresa suficientemente el merecimiento de pena en este caso" $"$.

\footnotetext{
${ }^{18}$ La sentencia tiene la particularidad añadida de que, conforme a la tesis tradicional, suma los importes correspondientes a cada una de las infracciones reiteradas - cada una susceptible de ser subsumida en diferentes hipótesis del art. 467 del Código Penal- para el establecimiento del marco penal base de la reiteración, que la sentencia sitúa de acuerdo a "la suma de las defraudaciones" en el supuesto del numeral primero de dicha norma, a saber, presidio menor en sus grados medio a máximo, y que consecuencia del aumento de un grado a partir del grado mínimo queda concretado en presidio menor en su grado máximo. Dicho modo de proceder, en este caso concreto, en comparación con la alternativa de adopción del marco del delito con pena mayor como marco primario del cálculo de pena (la pena prevista en el numeral segundo:
} 


\section{BESIO, Martín. “Aplicación del artículo 351 del Código Procesal Penal”.}

Recientemente, la STOP Temuco Rit 245-2014, de 28/01/2015 sostiene expresamente que el aumento en grado exigido por la reiteración de delitos de una misma especie se verifica desde el grado mínimo, en el contexto de reiteración de delitos de violación y abusos sexuales:

"Que, el delito de violación previsto sanción 361 del Código Penal, se castiga con la pena de presidio mayor en su grado mínimo a medio. Y, como se acreditó en el juicio el imputado fue condenado como autor del referido ilícito, en carácter de reiterado por lo debe aumentarse en un grado la pena desde el mínimo, quedando ésta en presidio mayor en su grado medio y concurriendo la agravante especial del articulo $368 \mathrm{del}$ Código Penal no se podrá aplicar en su mínimo.

Que, también se condenó al imputado como autor del delito de violación reiterado, previsto sancionado en artículo 362 del Código de castigo, con una sanción de presidio mayor en cualquiera de sus grados, que como tienen el carácter de reiterado debe aumentarse la pena en un grado desde el mínimo, quedando esta en presidio mayor en su grado medio y como le perjudica la agravante del artículo [368] del Código Penal, esta sanción queda fijada en presidio mayor en su grado máximo.

Que, igualmente se le condenó como autor del delito de abuso sexual infantil, que se sanciona con presidio menor en su grado máximo a presidio mayor en su grado mínimo. Pero como tiene el carácter de reiterado, debe aumentarse en un grado el mínimo que la ley ha asignado para éste delito, quedando fijada la pena en presidio mayor en su grado mínimo y como le perjudica la agravante del artículo 368 del Código Penal, no se podrá aplicar en su mínimo".

También realiza el aumento desde el grado mínimo la STOP Concepción Rit 4-2015, de 04/03/2015, en el contexto de delitos reiterados de violación:

"Que la pena asignada por la ley al delito de violación consta de tres grados de una divisible, esto es, con presidio mayor en cualquiera de sus grados y tratándose de delitos de la misma especie cometidos en forma reiterada y siendo más beneficioso en la aplicación de la pena lo previsto por el artículo 351 del Código Procesal Penal, procede aplicar la pena correspondiente a las diversas infracciones, estimadas como un solo delito, aumentadas en un grado, con lo que, atendida la cuantía de la pena legal, se ha de aplicar la de presidio mayor en su grado medio".

Utiliza el mismo sistema de incremento desde el grado mínimo la STOP Chillán Rit 692015, de 13/06/2015, tratándose de dos delitos reiterados de usura del art. 472 del Código Penal:

"En la especie, habiendo el acusado Víctor Hilario Riveros Aguilera condenado por dos delitos de usura, nos encontramos en la hipótesis de reiteración de delitos a la que refiere el artículo 351 del Código Procesal Penal, en virtud de lo cual las penas correspondientes a las diversas infracciones se considerarán como un solo delito, debiendo el tribunal aumentar en [uno] o dos grados. En el presente caso, teniendo presente que Riveros Aguilera resultó condenado por dos de los siete hechos que le

presidio menor en su grado medio), no altera la pena resultante, condicionada ésta por la técnica de aumento en grado a partir del grado mínimo adoptada por la sentencia, pero que en otros escenarios (aumento a partir del grado máximo) habría significado una diferencia sustancial de sanción. 


\section{Polít. crim. Vol. 10, № 20 (Diciembre 2015), Art. 5, pp. 543-596. \\ [http://www.politicacriminal.cl/Vol_10/n_20/Vol10N20A5.pdf]}

fueron atribuidos en la acusación, la pena solo se aumentará en un grado, y en ese contexto la pena se encuadra en el ámbito de presidio menor en su grado medio, pena que constituye un grado de una pena divisible, razón por la cual corresponde cumplir con lo ordenado en el artículo 67 del Código Penal, norma que en su inciso segundo impone al juzgador la obligación de imponer la pena en su mínimum cuando solo concurre una atenuante sin que medie agravante alguna (...)”.

Por otra parte, la STOP Santiago (4) Rit 43-2014, de 02/07/2014, razona al tenor del aumento de un grado en bloque por razón de la exasperación respecto de uno de los condenados en relación a la reiteración de dos delitos del art. 416 del Código de Justicia Militar, uno frustrado y el otro consumado; los que - por esa razón- incluye al alero del inciso segundo del art. 351 del Código Procesal Penal:

"Que respecto a los delitos de homicidio de Carabinero en ejercicio de sus funciones por los cuales fuera condenado Aliste Vega, si bien ambas conductas protegen los mismos bienes jurídicos, esto es la vida humana, el orden y seguridad pública, en atención a que el grado de desarrollo determinado en la especie es distinto -frustrado y consumado- éstas no pueden estimarse como un solo delito ya que tal circunstancia llevaría a asignar diferentes penas a tales ilícitos. Así entonces, la aplicación en este caso del inciso segundo del artículo 351 del Código Procesal Penal, significaría que el rango de pena a imponer se extendería desde presidio perpetuo simple a presidio perpetuo calificado".

También efectúa el aumento en bloque -en el contexto de reiteración de delitos de violación impropia- la STOP Santiago (2) Rit 186-2013, de 28/03/2013:

"En este caso, el delito de violación, en abstracto tiene una pena asignada por la ley de presidio mayor en cualquiera de sus grados, luego habiendo decidido el tribunal, en virtud de la cantidad de delitos cometidos y de las circunstancias particulares del caso ya analizadas, aumentar la pena en un grado en base a lo dispuesto en el inciso primero del artículo 351 del Código Procesal Penal, quedando en consecuencia, el piso o grado inferior de la sanción a imponer, constituido por la pena de presidio mayor en su grado medio.

A continuación, considerando que en la especie, concurre la atenuante del artículo 11 número 6 del Código Penal y la minorante del artículo 11 número 9 y de acuerdo a lo prevenido en el artículo 68 del Código Penal, el tribunal procederá a rebajar en dos grados la pena antes referida, quedando la pena a imponer en la de presidio menor en su grado máximo".

Tratándose del aumento de grado en escenarios no reglados, la Corte Suprema se ha pronunciado a través de la sentencia de la Corte Suprema (en adelante, "SCS") Rol 72242013, de 11/11/2013, providencia que resulta relevante no sólo porque constituye un buen reflejo de algunas de las problemáticas ya referidas, sino porque -además- contiene la adopción de decisiones trascendentes para los efectos del sistema general de individualización de la pena.

El contexto en el que se pronuncia la sentencia -en lo que a la cuantificación penal se refiere- es el siguiente: un recurso de nulidad interpuesto por la defensa a partir de la causal del art. 373 b) del Código Procesal Penal (error de derecho con influencia sustancial en lo 
BESIO, Martín. “Aplicación del artículo 351 del Código Procesal Penal”.

dispositivo del fallo), fundado en la desestimación por parte del tribunal a quo de la atenuante del art. $11.6^{\circ}$ del Código Penal bajo el argumento de la existencia de una condena previa por una falta penal, error (no concesión de la atenuante) que -a juicio del recursosupuso la imposición de una pena mayor a la que legalmente correspondía. El fallo del tribunal de instancia condenó al recurrente - sin la concesión formal de la atenuante- en calidad de autor de dos delitos reiterados de violación impropia del art. 362 del Código Penal, con la agravante especial del art. 368 del mismo cuerpo normativo, a la pena de quince años y un día de presidio mayor en su grado medio.

En dicho escenario, se destaca desde ya, la Corte Suprema rechazó el recurso bajo el argumento de que el error de derecho denunciado, de haberse configurado, no tuvo de todas formas incidencia en la pena impuesta (no existió influencia sustancial en lo dispositivo del fallo impugnado), por lo que la estructura argumentativa de la sentencia se centró en proyectar la cuantificación de la pena resultante al tenor de las diferentes opciones que -de acuerdo a la sentencia- entrega el art. 351 del Código Procesal Penal, a fin de demostrar que el error denunciado no fue decisivo. Y de dicho análisis proyectivo de cuantificación de pena se derivan -expresa y tácitamente- una serie de cuestiones relevantes.

En efecto, luego de constatar que la aplicación del art. 351 del Código Procesal Penal resulta más favorable para el condenado que el régimen de acumulación material del art. 74 del Código Penal, la sentencia razona - proyectando la determinación de la pena- al alero tanto del inciso primero como del inciso segundo de la regla de exasperación, con el objeto de demostrar la irrelevancia del error denunciado.

En una primera fase del análisis, la sentencia se centra en desarrollar las diferentes posibilidades de aumento de grado del marco penal base a partir de la inclusión de los delitos en el inciso primero del art. 351 del Código Procesal Penal, a través del siguiente razonamiento:

"En efecto, si se estima que los dos ilícitos acreditados en el fallo recurrido, pueden considerarse como un sólo delito conforme al inciso primero del precitado artículo 351, tomando cualquiera de ellos como base, debe aumentarse en un grado -al menos- la pena compuesta de presidio mayor en cualquiera de sus grados, pasando a presidio mayor en su grado medio a presidio perpetuo (si se eleva en un grado cada uno de los grados que componen esta pena), o a presidio perpetuo simple (si se eleva la pena desde su grado máximo), pero en ningún caso procedería concretar este aumento tomando como base únicamente el grado mínimo que compone esta pena compuesta, pues de lo contrario, al aumentarla en un grado por la reiteración, se arribaría a presidio mayor en su grado medio, corolario inaceptable por el contrasentido a que conduce, ya que quien comete dos o más delitos de violación impropia se expondría a una sanción menor -presidio mayor en su grado medio- que quien perpetra sólo una vez dicho ilícito -presidio mayor en su grado mínimo a máximo-".

En esta etapa del análisis, la sentencia estimó que de aceptarse que los ilícitos deben ser incorporados al alero del inciso primero de la regla de reiteración procede en primer lugar realizar el aumento -al menos, por ser imperativo- en un grado en virtud de dicha regla, para posteriormente -en un segundo paso, como se verá infra- otorgar aplicación a los efectos propios de las circunstancias modificatorias concurrentes, admitiendo expresamente 
en ese contexto dos posibilidades teóricas de incremento en grado y rechazando -también explícitamente- la alternativa restante. Así, la sentencia asume como alternativas válidas tanto la técnica de aumento en bloque ("si se eleva en un grado cada uno de los grados que componen esta pena") como el procedimiento de aumento a partir del grado máximo del marco penal primario ("si se eleva la pena desde su grado máximo"), rechazando no obstante la fórmula de aumento a partir del grado mínimo ("pero en ningún caso procedería concretar este aumento tomando como base únicamente el grado mínimo que compone esta pena compuesta"), por razones de carácter valorativas ("por el contrasentido a que conduce").

Al margen de que no existe una toma de posición específica respecto del modo normativamente correcto de realizar el aumento en grado tratándose de marcos penales compuestos, pues subsisten en la sentencia como alternativas viables tanto el aumento en grado a partir del grado máximo como el incremento en bloque, con lo que -al fin y al cabo- se esquiva el problema esencial; de todas formas la Corte Suprema rechaza explícitamente la técnica de aumento desde el grado mínimo. Y el argumento que utiliza para justificar dicho aserto constituye un antecedente relevante al interior de esta problemática: el aumento en grado desde el grado mínimo conduce a una inconsistencia valorativa, a un contrasentido ${ }^{19}$, toda vez que genera como consecuencia una sanción menor -para una reiteración de delitos- que la asociada a la comisión de un solo delito.

$\mathrm{El}$ argumento, con todo, debe ser matizado, porque en los mismos términos expuestos por la sentencia resulta equívoco. La sentencia argumenta que el marco penal resultante del aumento en grado a partir del grado mínimo, a saber, presidio mayor en su grado medio, constituye una sanción menor para una pluralidad de delitos reiterados que la pena asociada a la comisión de un solo delito, esto es, una sanción inferior a la pena de presidio mayor en sus grados mínimo a máximo; comparación entre ambas hipótesis que luego permite afirmar -dada la diferencia entre ambas sanciones- el contrasentido punitivo al que conduciría el aumento desde el grado mínimo. Pero ocurre que la comparación en abstracto no es correcta porque la pena de presidio mayor en su grado medio no es una pena menor ni tampoco una pena mayor a la pena de presidio mayor en sus grados mínimo a máximo (la segunda es mayor a la primera en tanto contiene un grado de penalidad superior -presidio mayor en su grado máximo- que no prevé la primera; pero ésta es al mismo tiempo menor a la segunda porque contiene un grado de pena inferior que no integra aquella -presidio mayor en su grado mínimo-, por lo que en abstracto no es posible afirmar que el aumento desde el grado mínimo genere para una pluralidad de delitos una pena inferior a la asignada a la comisión de un solo delito.

Sólo una comparación en concreto -desechada la evaluación en abstracto- es la que permite ponderar la corrección del argumento y del contrasentido punitivo denunciado, el que se encuentra subordinado a los efectos de las circunstancias que se presenten y también, en su caso, a los parámetros del art. 69 del Código Penal y a sus efectos sobre el

\footnotetext{
${ }^{19}$ Dicho argumento ha sido esgrimido también por OLIVER CALDERÓN, "La exasperación”, cit. nota n 9, p. 178 y ss., pero subordinado a un objetivo diferente, a saber, para descartar la fórmula de aumento en bloque y validar así - de acuerdo a su opinión- el incremento a partir del grado máximo; sobre ello, infra.
} 


\section{BESIO, Martín. “Aplicación del artículo 351 del Código Procesal Penal”.}

marco penal; en definitiva, un argumento condicionado por las particularidades de cada caso y que por ello carece de validez general.

De hecho, en este caso, en razón de las circunstancias existentes (la atenuante que se pretende y la agravante especial concurrente), el argumento desarrollado para desvirtuar el aumento en grado desde el grado mínimo deviene en incorrecto. Así, si se proyectase el razonamiento íntegro de individualización de la pena (incluidos los efectos de las circunstancias) que hubiese realizado la sentencia -y que no efectuó- se arriba a la conclusión de que, por el contrario, dos delitos reiterados de violación sí tienen asignada mayor pena que la hipótesis de comisión por una vez de dicho ilícito. En efecto, sobre la base de un marco penal de presidio mayor en cualquiera de sus grados, una vez realizado el aumento en grado desde el grado mínimo se arriba -como afirma la sentencia- a un marco de presidio mayor en su grado medio. Luego, concurren dos circunstancias, la pretendida atenuante ordinaria del art. $11.6^{\circ}$ y la agravante especial del art. 368, ambos del Código Penal, que deben compensarse racionalmente toda vez que su aplicación sucesiva -que no obstante prescribe la sentencia- resulta en este caso inviable, por lo que dado que sus efectos contrapuestos son de la misma magnitud (ambas son circunstancias de eficacia ordinaria) se anulan recíproca y completamente, quedando depurado así el marco penal en presidio mayor en su grado medio, al interior del cual -como hizo la sentencia del tribunal a quo- se impondría la cuantía de pena en el mínimo posible (diez años y un día) en atención al art. 69 del Código Penal. Y dicha pena asociada a dos delitos reiterados constituye una sanción superior a aquella derivada de la comisión de ese delito por una sola vez. Así, tratándose de un solo delito el marco penal base es de presidio mayor en cualquiera de sus grados, marco que luego de la compensación racional de las circunstancias se mantiene inalterable, debiendo fijarse entonces en su interior-conforme al art. 69 del Código Penal, tal como decidió el tribunal a quo- la pena mínima, esto es, cinco años y un día de presidio mayor en su grado mínimo.

En consecuencia, dos delitos reiterados en que se adopta el aumento en grado desde el grado mínimo tienen asignada una pena mayor (diez años y un día de presidio mayor en su grado medio) que la correspondiente a la comisión de uno sólo de tales ilícitos (cinco años y un día de presidio mayor en su grado mínimo). Desaparece, entonces, el contrasentido valorativo reprochado al incremento a partir del grado mínimo ${ }^{20}$.

El mismo resultado general se deriva de un escenario normativo más simple de cuantificar, en el que se esquiven las dificultades que pueden presentarse en relación a la posibilidad de compensación racional de circunstancias comunes y especiales ${ }^{21}$. Piénsese en el mismo

\footnotetext{
${ }^{20}$ A menos que se entienda que la diferencia punitiva entre ambas penas (de un grado de pena) resulta insuficiente para diferenciar adecuadamente ambos supuestos (dos delitos reiterados y un solo delito), manteniéndose entonces dicho contrasentido valorativo, aunque bastante atenuando en comparación al denunciado; asunción de todos modos inconsistente con el objetivo vinculado al régimen de reiteración de delitos de una misma especie, a saber, morigerar los efectos excesivos derivados del sistema de acumulación material, objetivo que, cumpliéndose en este caso, mantiene de todas formas una distinción punitiva proporcional (de un grado de pena) al desvalor que representan ambos supuestos.

${ }^{21}$ Sobre todo considerando que la Corte Suprema no advierte la posibilidad de compensación entre ambas circunstancias y les otorga una aplicación sucesiva en la depuración del marco penal; infra en el texto, y ns. 22 y 23.
} 
delito, pero ahora con la concurrencia de sólo una circunstancia atenuante ordinaria y en que -como en el supuesto anterior- los baremos asociados a la decisión cuantitativa de pena impliquen la imposición de la cuantía de pena exacta en el límite inferior del marco penal concreto. En ese caso, tratándose de dos delitos reiterados y realizando el aumento de un grado a partir del grado mínimo resultará un marco penal de presidio mayor en su grado medio. Siguiendo el orden de preferencia delineado por la sentencia (que posterga para un segundo momento la aplicación de las circunstancias), luego de ello producirá sus efectos la atenuante concurrente, quedando el marco penal concreto situado en el mínimum de presidio mayor en su grado medio y, la pena, en definitiva, en el mínimo de dicho marco (diez años y un día). Respecto de la comisión de un solo delito, el marco penal base (presidio mayor en cualquiera de sus grados) por los efectos de la atenuante-que excluye el grado máximo de penalidad- quedará constituido por la pena de presidio mayor en sus grados mínimo a medio, al interior del cual se fijará la cuantía específica de sanción en su mínimo, esto es, en cinco años y un día de presidio mayor en su grado mínimo.

La pena asignada a la reiteración de dos delitos efectuando el aumento derivado de la exasperación desde el grado mínimo es mayor (un grado de diferencia) a la pena asociada a la comisión de un solo delito, eliminándose entonces el contrasentido punitivo reprochado como consecuencia del aumento desde el grado mínimo.

Por contra, un supuesto en el que sí se verificaría en concreto tal inconsistencia punitiva se encuentra en el caso de concurrencia de dos o más agravantes, escenario reglado y en virtud del cual -por mandato legal expreso- el eventual aumento en grado derivado de la presencia de agravantes se realiza desde el grado máximo. Así, en el caso de dos delitos reiterados de violación impropia con dos agravantes, el marco penal provisional quedará situado -aumentando un grado desde el mínimo en razón de la reiteración- en presidio mayor en su grado medio, y por efecto de las agravantes concurrentes -y sólo si se les otorga la máxima eficacia discrecional admisible - en presidio mayor en su grado máximo; pena inferior -ya en abstracto- a la asignada a la comisión de un solo delito de violación impropia con dos agravantes, a saber, la pena de presidio perpetuo simple, resultado del aumento de un grado en virtud de las agravantes realizado desde el grado máximo de un marco penal de presidio mayor en cualquiera de sus grados.

En suma, la técnica de aumento a partir del grado mínimo no genera ni en abstracto ni en concreto para todos los supuestos contrasentidos de orden valorativo.

Al margen de ello, el razonamiento de la sentencia se centra luego en analizar las consecuencias derivadas de realizar el aumento de grado en bloque a través del inciso primero del art. 351 del Código Procesal Penal, una vez descartado -como ya se expuso-el incremento a partir del grado mínimo; concluyendo la irrelevancia del error objeto de la causal:

"Pues bien, si se optara por materializar este incremento de un grado producto de la reiteración, aumentando cada uno de los grados de esta pena compuesta, resultará, como se ha adelantado, una sanción de presidio mayor en su grado medio a perpetuo, y si posteriormente, por mandato del artículo 368 ya referido, se excluye el grado medio del presidio mayor, y por otra parte, se resta el presidio perpetuo en virtud de la 


\section{BESIO, Martín. “Aplicación del artículo 351 del Código Procesal Penal”.}

mitigante pretendida por el recurrente, el cuadro final -presidio mayor en su grado máximo-, se ajusta a lo decidido por los sentenciadores, que además fijan la sanción en la mínima cuantía del grado".

No obstante la proyección de la cuantificación asociada al aumento en bloque, lo relevante de destacar es que -en dicha proyección- la sentencia atribuye un orden específico de prelación de las reglas convergentes para la producción de sus efectos sobre el marco penal, en el contexto del inciso primero del art. 351 del Código Procesal Penal.

Así, de acuerdo a la sentencia, en el caso de infracciones que pueden ser consideradas como un solo delito primero recibe aplicación el aumento en grado prescrito por la exasperación, luego -en un segundo lugar- produce sus efectos la circunstancia especial y sólo con posterioridad opera la circunstancia ordinaria. Ello supone -tanto expresa como tácitamente- una postura específica sobre algunas cuestiones relevantes en materia de individualización de la pena. Por de pronto, asigna al inciso primero un sistema específico de cuantificación si concurren circunstancias modificativas: primero se aplica el aumento derivado de la reiteración y posteriormente producen sus efectos las circunstancias, procedimiento diverso - como se verá- al que asigna la propia sentencia al inciso segundo de la regla de exasperación. En segundo término, la Corte Suprema no advierte la posibilidad -ni tampoco realiza el ejercicio- de compensación racional de circunstancias comunes y especiales, aunque éstas sean, como en este caso, de eficacia ordinaria, posibilidad admitida tanto por la jurisprudencia ${ }^{22}$ como por la doctrina $^{23}$ y que hubiese determinado en el caso concreto una diferencia de pena relevante ${ }^{24}$. Por último, y como consecuencia de la exclusión de la posibilidad de compensación, la sentencia asume una preordenación específica de concurrencia sucesiva de las circunstancias: primero la circunstancia especial y posteriormente la circunstancia común, decisión que se justifica en otro apartado en el tenor literal del art. 368 del Código Penal, pero que -al mismo tiempo-

\footnotetext{
${ }^{22}$ Aun cuando no es posible aseverar categóricamente la admisión general por parte de la jurisprudencia del ejercicio de compensación racional de circunstancias comunes y especiales, dado el -casi- inexistente desarrollo argumental del problema que se constata en las sentencias que se pronuncian al respecto, puede destacarse que normalmente se admite en la medida de que las circunstancias que se integran al ejercicio compensatorio sean de eficacia ordinaria; así -como ejemplo paradigmático- la compensación racional de las atenuantes genéricas del art. $11.6^{\circ}$ y $11.9^{\circ}$, en su caso, con la agravante especial -de eficacia ordinaria- del art. 456.bis. $3^{\circ}$, todas reglas del Código Penal. Al respecto, entre otras, la SCA Valdivia Rol 354-2010, de 01/01/2010 y la SCA San Miguel Rol 70-2011, de 04/03/2011.

${ }^{23}$ En general, existe consenso dogmático en que es posible la compensación de circunstancias de eficacia ordinaria, ya sean comunes o especiales, y en que aquellas de eficacia extraordinaria no pueden integrar la operación de compensación, ya sea que concurran entre sí o con circunstancias de eficacia ordinaria; consenso advertido por COUSO SALAS, Jaime, “Artículo 66”, en: COUSO, Jaime; HERNÁNDEZ, Héctor (Dirs.), Código Penal comentado, parte general. Doctrina y jurisprudencia, Santiago: Ed. AbeledoPerrot, 2011, pp. 539-897, p. 596, con las referencias correspondientes.

${ }^{24}$ Así, de haberse admitido el ejercicio compensatorio luego del aumento en grado en bloque, si se asume su anulación recíproca - dado los mismos efectos de depuración del marco que ambas conllevan: ambas son de eficacia ordinaria- el marco provisional se mantendría en presidio mayor en su grado medio a perpetuo simple, el que si bien en abstracto no es menor ni mayor al marco determinado por la sentencia del tribunal a quo (presidio mayor en su grado máximo), sí genera en concreto una pena menor dado que dicho tribunal fijó la cuantía de pena en el mínimo de dicho marco, por lo que de replicar dicha decisión -dado que los factores del art. 69 del Código Penal se mantienen inalterables- la pena habría sido impuesta en diez años y un día de presidio mayor en su grado medio.
} 


\section{Polít. crim. Vol. 10, № 20 (Diciembre 2015), Art. 5, pp. 543-596. [http://www.politicacriminal.cl/Vol_10/n_20/Vol10N20A5.pdf]}

se advierte como el orden de procedencia general normativamente correcto $^{25}$ y que resulta inverso al orden propuesto por la doctrina mayoritaria ${ }^{26}$.

Curiosamente, al margen de lo anterior, la sentencia no realiza el ejercicio de proyectar la pena derivada de efectuar el aumento desde el grado máximo, posibilidad que admite como válida expresamente unas líneas antes y que hubiese implicado la imposición de una pena superior a la decidida por el tribunal a quo, a saber, una pena de presidio perpetuo simple.

Respecto de la proyección de pena adscrita al inciso segundo del art. 351 del Código Procesal Penal, se pronuncia la sentencia en el siguiente sentido:

"Por último, si se considerara que por la naturaleza de los ilícitos de violación materia de la condena, éstos no pueden catalogarse como un solo delito, en correspondencia al inciso segundo del artículo 351 en estudio, tomando la pena de presidio mayor en su grado medio, resultado como ya dijimos del influjo de los artículos 368 del Código Penal -que excluye el grado mínimo del presidio mayor-, y 68, inciso segundo, del mismo texto, en relación con el artículo $11 \mathrm{~N}^{\circ} 6$ que persigue la defensa -que descarta el grado máximo del presidio mayor-, tal grado deberá incrementarse -al menos- a presidio mayor en su grado máximo por la reiteración, marco en cuya mínima cuantía se ha determinado la sanción por los sentenciadores".

\footnotetext{
${ }^{25} \mathrm{El}$ apartado en el que se advierte la preferencia operativa de las circunstancias especiales en desmedro de las comunes, es el siguiente: “(...) [p]or perjudicar al encartado la agravante del inciso primero del artículo 368 del mismo texto legal queda excluido el grado mínimo de la pena prevista para este delito, operación que debe efectuarse antes de la actuación de las circunstancias genéricas modificatorias de responsabilidad penal, más aún si el artículo citado prescribe que sus efectos se concretan sobre la pena señalada al delito". Si bien la sentencia deriva un mandato de aplicación preferente de la circunstancia especial de la propia regla que la consagra (art. 368 del Código Penal), toda vez que la norma reconduce los efectos agravatorios que prescribe a "la pena señalada al delito", expresión que la Corte Suprema interpreta -se entiende- como una alusión normativa al marco penal abstracto; de todas formas -y es lo que interesa destacar aquí- pareciera asumir que dicho modo de proceder (primero circunstancias especiales y luego comunes, excluida la posibilidad de compensación) debe ser la regla general, asunción que se deriva inequívocamente de la expresión "más aún" que emplea luego de establecer dicho orden de aplicación y- que asocia al respaldo normativo que le concede el art. 368. En otras palabras, simplificando, la Corte Suprema entiende que el procedimiento general es aplicar primero las circunstancias especiales y luego las comunes ("operación que debe efectuarse antes de la actuación de las circunstancias genéricas modificatorias de responsabilidad penal"), orden que se encuentra ratificado por el art. 368 del Código Penal ("más aún si el artículo citado prescribe que sus efectos se concretan sobre la pena señalada al delito").

${ }^{26} \mathrm{Al}$ margen del problema de diferenciar entre tipos calificados y circunstancias especiales, la doctrina, por el contrario, parece alinearse en el sentido de que -en el contexto de presencia conjunta de circunstancias comunes y especiales- deben producir primero sus efectos las comunes y posteriormente las especiales (así, entre otros, ETCHEBERRY, Alfredo, Derecho Penal, parte general, t. II, $3^{\circ}$ ed., Santiago: Editorial Jurídica, 1998, pp. 189-190 [cit.: Derecho penal]); generándose el problema (adicional a -y en el contexto de- la ausencia de una regla expresa que provea de esa solución para todos los supuestos) de que dicha forma de proceder no siempre resulta más favorable para el condenado. Así, por ejemplo, en el caso de un delito de hurto del art. $446.1^{\circ}$ del Código Penal (presidio menor en sus grados medio a máximo) con la presencia de dos agravantes ordinarias que determinen el aumento en un grado y la atenuante especial del 456 (si es que efectivamente es una atenuante y no genera un tipo privilegiado); en ese caso, si se siguiese el orden propuesto por la doctrina el marco penal resultante sería de presidio menor en su grado máximo, pena superior a aquella resultante de una inversión del orden de aplicación (tal y como propone la Corte Suprema: primero especiales y luego comunes), pues en este escenario alternativo el marco resultante sería de presidio menor en su grado medio.
} 


\section{BESIO, Martín. “Aplicación del artículo 351 del Código Procesal Penal”.}

El razonamiento se encuentra subordinado al tenor literal del inciso segundo de la regla de reiteración, que impone una aplicación preferente de los efectos de las circunstancias por sobre el aumento en grado, orden de prelación inverso al asumido por la sentencia para el caso del inciso primero y que, en concreto, no genera un escenario alternativo de técnicas de incremento de grado en razón de la reiteración, al verificarse éste -por los efectos previos de las circunstancias- sobre un marco penal compuesto por solo un grado de penalidad.

En suma, en concepto de la Corte Suprema el art. 351 del Código Procesal Penal alberga dos sistemas diferentes de cuantificación en sus incisos primero y segundo. Asimismo, el máximo tribunal admite como alternativas válidas para proceder al aumento en grado derivado de la exasperación tanto el incremento en bloque como el realizado a partir del grado máximo, descartando la técnica de aumento desde el grado mínimo; aun cuando las razones que se esgrimen para justificar dicho rechazo no son del todo correctas.

En todo caso, el enérgico rechazo asumido por la Corte Suprema para la técnica de aumento a partir del grado mínimo debe relativizarse, pues en una sentencia posterior dictada en un escenario estructuralmente similar (recurso de nulidad fundado en la no concesión de una circunstancia atenuante) el máximo tribunal mantuvo una posición diferente al validar tácitamente dicha forma de incremento, sin advertir -ni pronunciarse sobre- el problema.

El razonamiento relevante se encuentra contenido en la SCS Rol 14.346-2014, de 19/08/2014:

"Vidal Duarte resultó sancionado como autor del delito establecido en el artículo $97 \mathrm{~N}^{\circ}$ 4 inciso final del Código Tributario, para el que se prescribe la pena de presidio menor en su grado medio a máximo. Por haber reiteración del mismo delito, como estableció el fallo, la pena se incrementó en un grado, lo que da como resultado el presidio menor en su grado máximo. Dentro de la extensión de este marco penal, sin modificatorias de responsabilidad que considerar, los sentenciadores podían recorrerlo completamente, pero impusieron la mínima cuantía de la pena, esto es, tres años y un día de presidio menor, de manera que aún de acogerse la minorante reclamada, la sanción no ha podido ser de menor entidad, con lo cual la alegación que se formula carece de influencia en lo dispositivo del fallo y conlleva el rechazo de esta sección del recurso" 27

Mientras la jurisprudencia opera a través de las tres posibilidades teóricas de incremento en grado en el contexto de la regla de reiteración, siendo posible constatar una tendencia importante orientada al aumento a partir del grado mínimo, posibilidad que al mismo tiempo ha sido descartada expresamente por la Corte Suprema; el debate dogmático se ha

\footnotetext{
${ }^{27}$ Aun cuando acierta la sentencia en que la eventual concesión de la atenuante, realizando el aumento en grado -como hizo el tribunal a quo- desde el grado mínimo, no hubiese significado una variación sustancial del marco penal resultante (sólo habría variado si se hubiese realizado el incremento a partir del grado máximo, procedimiento también validado por el máximo tribunal, pero que hubiese implicado una pena superior a la impuesta, esto es, en perjuicio y no beneficio del condenado), de todas formas se acepta el incremento desde el grado mínimo: "[p]or haber reiteración del mismo delito, como estableció el fallo, la pena se incrementó en un grado, lo que da como resultado el presidio menor en su grado máximo".
} 


\section{Polít. crim. Vol. 10, № 20 (Diciembre 2015), Art. 5, pp. 543-596. \\ [http://www.politicacriminal.cl/Vol_10/n_20/Vol10N20A5.pdf]}

centrado esencialmente en la dualidad constituida por el aumento en bloque y el incremento desde el grado máximo.

La doctrina mayoritaria se ha alineado rechazando el incremento desde el grado máximo y asumiendo como correcto el aumento en bloque ${ }^{28}$, aunque -como regla general- sin desarrollar los fundamentos que justificarían dicha posición ${ }^{29}$, los que se reconducen normalmente a los planteamientos expuestos por Novoa Monreal ${ }^{30}$.

En primer lugar, se esgrime un argumento normativo -tan simple como categóricovinculado a la autonomía legal (como pena) de cada uno de los grados de penalidad que integran un marco penal compuesto, la que justifica y obliga a extender a todos ellos los efectos derivados del aumento. En términos simples, de acuerdo al art. 57 del Código Penal cada grado de pena divisible constituye una pena distinta y, por ende, todo aumento de grado debe abarcar a todas y a cada una de las penas -distintas- que integran el marco penal (lo que sólo es posible a través del aumento en bloque) y no sólo alcanzar a la mayor o menor de dichas penas autónomas (como se verifica si se realiza el aumento a partir del grado máximo o mínimo del marco penal base).

En segundo término, desde la óptica de una interpretación de la ley penal a contrario sensu, se sostiene que "(...) cuando la ley ha querido que el aumento parta del máximo, lo dice expresamente (art. 68), de modo que a falta de precepto que así lo ordene, no puede entenderse en esa forma el aumento" 31 ; argumento que no resulta decisivo dada su flexibilidad intrínseca, pues nada impide en el contexto de la interpretación lógica del art. 68 del Código Penal en comparación al art. 351 del Código Procesal Penal sostener lo contrario - como se ha sostenido-, esto es, aducir que la primera regla prevé una suerte de fórmula general de realizar el aumento de grado $^{32}$, replicable para todas las hipótesis de incremento.

Debe destacarse que en este escenario no se trata de un problema de aplicación analógica de la ley penal (si así fuese, la extensión al régimen de reiteración del aumento desde el grado máximo que prevé el art. 68 del Código Penal se encontraría desde ya prohibida, cerrándose el debate, en tanto perjudicial para el condenado), toda vez que la posibilidad de aumento desde el grado máximo que se pretende incorporar o restar de la regla de exasperación es una posibilidad que se encuentra comprendida dentro del sentido literal

\footnotetext{
${ }^{28}$ COUSO SALAS, “Comentario previo”, cit. nota ${ }^{\circ} 7$, p. 522.

${ }^{29}$ Entre otros, GARRIDO MONTT, Derecho penal, cit. nota $n^{\circ}$ 7, p. 320, luego de exponer las distintas posibilidades teóricas de aumento en grado, sostiene que "[1]a solución más correcta es aquella que consiste en subir cada uno de los distintos grados de la pena que conforman toda su extensión, y no hacerlo desde su máximo"; también CURY URZÚA, Derecho penal, cit. nota $\mathrm{n}^{\circ}$ 7, p. 762, refiere que los fallos operan tanto a través del aumento desde el máximo como en bloque, destacando que "[e]sta última es la opinión correcta", para adherir luego (n. 11) a la posición de Novoa Monreal.

${ }^{30}$ NOVOA MONREAL, Eduardo, Curso de Derecho Penal chileno, parte general, t. II, $3^{\circ}$ ed., Santiago: Ed. Jurídica, 2005, pp. 357-358 [cit.: Curso].

${ }^{31}$ NOVOA MONREAL, Curso, cit. nota ${ }^{\circ} 30$, p. 357.

32 Así, OLIVER CALDERÓN, “La exasperación”, cit. nota $n^{\circ}$ 9, p. 180, quien advierte la debilidad del argumento (que utiliza parcialmente para afirmar la corrección del aumento desde el grado máximo) y, por ello, destaca que "(...) en todo caso, lo relevante es que una interpretación a contrario sensu conduce a un contrasentido valorativo", argumento que esgrime como central; infra, en el texto principal.
} 
BESIO, Martín. "Aplicación del artículo 351 del Código Procesal Penal”.

posible de esta última (es una interpretación que no desborda los límites semánticos impuestos por el texto "aumentándola en uno o dos grados"); por lo que se trata, en definitiva, de un problema de admisibilidad de una interpretación extensiva del precepto ${ }^{33}$. De todos modos, en un contexto de interpretación del enunciado normativo que prevé el aumento en grado al interior de la regla de reiteración, no obstante tratarse de una regla penal sustantiva ${ }^{34}$ se encuentra incorporada en el Código Procesal Penal, siendo aplicable a su respecto el mandato de interpretación restrictiva que prevé su art. 5, imperativo que avala la tesis de proscripción del aumento desde el grado máximo en tanto éste genera -en comparación con las otras alternativas de incremento- una restricción o afectación mayor de la libertad y otros derechos del imputado a través de la (mayor) pena que conlleva.

Por último, se esgrime que el sistema de aumento desde el grado máximo genera un marco penal compuesto por un grado de pena, aplicándose a su respecto en caso de pluralidad de atenuantes el régimen del art. 67 del Código Penal, que sólo prevé la posibilidad de disminución de dos grados, y que -por ello- deviene en perjudicial en comparación con el régimen contenido en el art. 68 del Código Penal, que admite una disminución hasta en tres grados tratándose de dos o más atenuantes sin agravantes, supuesto más favorable al que quedaría sujeto el marco penal derivado del aumento en bloque.

Aun cuando esta línea argumental tiene una cierta plausibilidad normativa, en la medida que refleja las diferentes consecuencias que podrían derivarse formalmente de cada sistema de incremento (y que cabría extender al sistema de aumento desde el grado mínimo, que implica la generación de marcos integrados por un grado de penalidad), no es concluyente. Por una parte, porque la dicotomía punitiva que presenta es contingente, subordinada a la presencia de una pluralidad de atenuantes que no se verifica en todos los escenarios, pero que incluso presentándose en el caso concreto deviene también en eventual, pues la posibilidad concreta de disminución de tres grados de pena -en la práctica, como regla absolutamente general- suele ser excepcional. Por la otra, porque la dicotomía denunciada no es tal, ya que nada impide asimilar ambos regímenes por vía analógica -en beneficio del condenado- y por ello extender la posibilidad normativa de disminución de hasta tres grados a los marcos penales reglados por el art. 67 del Código Penal, en ausencia de razones que justifiquen esta-incomprensible- distinción normativa.

Recientemente un sector de la doctrina -que puede estimarse como minoritario- ha defendido para el régimen de acumulación jurídica otro sistema de aumento en grado.

Matus Acuña, a propósito del régimen de cálculo de pena que debe presidir a ambos incisos del art. 351 del Código Procesal Penal, pareciera entender que el incremento debe realizarse desde el grado mínimo, pues, en su opinión:

“(...) el aumento de grado es obligatorio y debe hacerse a partir de la pena concreta determinada, aplicando las circunstancias que sean del caso. Es por ello que, no concurriendo circunstancias que modifiquen un marco penal compuesto de dos o más

\footnotetext{
${ }^{33}$ MIR PUIG, Santiago, Derecho Penal, parte general, $9^{\circ}$ ed., Barcelona: Ed. Reppertor, 2011, p. 115.

${ }^{34}$ Al mismo tiempo, no obstante su inclusión en el Código Procesal Penal se trata de una regla de determinación de la pena de orden sustantivo; así, la SCS Rol 4608-2013, de 30/01/2014.
} 
grados, el aumento puede hacerse a partir del grado mínimo de éstos, asumiendo que éste corresponde a la pena determinada". 35

El autor, no obstante (y porque no pareciera formar parte del análisis que efectúa en esa parte del texto), no desarrolla el argumento ni entrega otros fundamentos, por lo que -al margen de lo obvio- no es posible un análisis adecuado de la propuesta, si es que a través de ella se pretende justificar el aumento desde el mínimo.

En ese contexto, el problema que presenta es que pareciera asimilar dos supuestos distintos, a saber, el constituido por un delito reiterado sin circunstancias y el asociado a un delito reiterado respecto del que concurre una atenuante de responsabilidad (tratándose de un marco penal compuesto por dos grados), atenuante cuyo efecto sobre el marco penal es precisamente situarlo en el grado mínimo de penalidad (que se asume como la pena determinada para un delito sin presencia de circunstancias) y a partir del cual se entiende debe realizarse el aumento derivado de la reiteración. La propuesta consiste en asumir que en ausencia de circunstancias puede entenderse que la pena determinada para un delito reiterado es aquella situada en el grado mínimo de un marco compuesto por dos grados de penalidad, en tanto ese es precisamente el mismo escenario que se presenta para un delito reiterado con concurrencia de una circunstancia atenuante -hipótesis normativamente diferente- y respecto del cual - dicho sea de paso- no se presenta el problema de dilucidar si el aumento se realiza o no a partir del grado mínimo, pues se tratará de un marco que integra sólo un grado de pena. Probablemente Matus Acuña no pretende defender el aumento en grado a partir del mínimo, sino que -cuestión distinta- intenta dar aplicación al art. 351 del Código Procesal Penal (y al sistema de cuantificación que exige determinar la pena con todas sus circunstancias antes de proceder al aumento de grado) en un escenario probable al interior del régimen de reiteración, a saber, cuando no se presentan circunstancias; escenario en el que propone que la pena determinada -a partir de la cual procede el aumento- sea entendida como el grado mínimo del marco penal ${ }^{36}$.

En todo caso, subsiste el yerro conceptual, pues tal asunción importa equiparar dos supuestos normativamente distintos, el de una reiteración de delitos sin presencia de circunstancias con el de una reiteración delictiva en que se verifique la presencia de una atenuante de responsabilidad (o, en el caso de un marco compuesto por tres grados, con un delito reiterado con circunstancias de distinto signo en que como resultado de la compensación de ellas subsista una atenuante). En definitiva, tratándose de un marco penal compuesto por dos o más grados de pena sin la presencia de circunstancias, la pena determinada -aquella que constituye la base del aumento- es simplemente ese marco penal en toda su extensión; marco respecto del cual se genera el problema de dilucidar el modelo de incremento en grado derivado de la exasperación.

El debate sobre el procedimiento correcto de aumento en grado en escenarios no reglados se ha visto revitalizado recientemente por Oliver Calderón, quien junto con controvertir los

\footnotetext{
${ }^{35}$ MATUS ACUÑA, "Proposiciones", cit. nota $\mathrm{n}^{\circ}$ 1, pp. 536-537.

${ }^{36}$ Avala esta interpretación la precisión acotada en la n. 34, MATUS ACUÑA, "Proposiciones", cit. nota $n^{\circ} 1$, p. 537: "[c]omo el cálculo se hace «con las circunstancias del caso», se cumple con la ley si sólo se toma en cuenta el grado mínimo de la pena mayor (...)".
} 


\section{BESIO, Martín. “Aplicación del artículo 351 del Código Procesal Penal”.}

argumentos tradicionales formulados en defensa del aumento en bloque ha introducido una nueva línea argumental que avalaría -en su opinión- la técnica de aumento desde el grado máximo, en el contexto de la regla de reiteración de delitos de una misma especie.

El argumento principal es de corte sistemático y se articula bajo la pretensión de demostrar el contrasentido valorativo que conllevaría el aumento de grado en bloque en comparación con los efectos asignados por el legislador a la presencia de una pluralidad de agravantes, en el caso de marcos compuestos. Para tales efectos, Oliver Calderón propone el siguiente escenario de comparación: por una parte, un delito de robo por sorpresa (presidio menor en sus grados medio a máximo) con dos agravantes, y por la otra, dos delitos reiterados de robo por sorpresa sin la presencia de circunstancias modificatorias; supuestos cuyos resultados punitivos proyecta y luego coteja para demostrar la inconsistencia valorativa que en tal escenario genera el aumento en bloque. En el primer supuesto, las posibilidades de determinación de la pena son dos: el tribunal otorga la mínima eficacia imperativa asociada a la pluralidad de agravantes, con lo que el marco penal quedaría situado - por la exclusión del grado mínimo- en presidio menor en su grado máximo; o aplica su efecto máximo discrecional admisible, aumentando un grado desde el grado máximo y construyendo un marco superior de presidio mayor en su grado mínimo. Tratándose del segundo supuesto dos delitos reiterados- el marco penal resultante, de proceder al aumento de grado en bloque, está constituido por las penas de presidio menor en su grado máximo a presidio mayor en su grado mínimo.

En ese contexto, de acuerdo al autor, de realizarse el aumento en bloque se generaría “(...) un marco penal compuesto por exactamente los mismos grados que podría imponer el tribunal en la hipótesis de un solo robo por sorpresa acompañado de dos agravantes", lo que

“(...) demuestra la incorrección de esta forma de aumentar la pena, ya que conduce al contrasentido de apreciar de la misma manera dos situaciones que, en su esencia, son valorativamente distintas: la de un delito (con dos agravantes) y la de dos o más delitos. El dato accidental de la pluralidad de agravantes no puede pasar por alto la evidente diferencia que existe a nivel de merecimiento y de necesidad de pena, entre la comisión de un solo delito y la de varios delitos". 37

Sin perjuicio de una aparente plausibilidad, el argumento debe ser objeto de reparos.

Por de pronto, el presupuesto base del argumento es equivoco (o al menos confuso), pues no es efectivo que -en el ejemplo propuesto- de realizarse el aumento en bloque se genera para la reiteración de delitos un marco "compuesto por exactamente los mismos grados" que el asociado a un solo delito con dos agravantes. No es correcto porque dependiendo de los efectos sobre el marco penal que otorgue el tribunal a la pluralidad de agravantes se generará en cada caso un marco penal diferente $-\mathrm{y}$, por cierto, no integrado por exactamente los mismos grados- que el derivado del aumento en bloque. Así, de otorgar la máxima eficacia discrecional a la pluralidad de agravantes, el marco penal resultante es de presidio mayor en su grado mínimo, pena mayor en abstracto y diferente a la pena

${ }^{37}$ OLIVER CALDERÓN, "La exasperación”, cit. nota n 9, p. 179. Como se advertirá, el argumento es similar al utilizado por la SCS Rol 7224-2013, de 11/11/2013 (supra, en el texto principal) para rechazar el aumento desde el grado mínimo, mas sin extenderlo -como sí realiza el autor-al aumento en bloque. 
construida a través del aumento en bloque, esto es, presidio menor en su grado máximo a presidio mayor en su grado mínimo (la primera es una pena integrada por un grado de penalidad, mayor a la segunda, compuesta de dos grados de pena). Y si el tribunal otorgase a las agravantes la mínima eficacia imperativa, el marco resultante es de presidio menor en su grado máximo, que constituye una pena menor y también diferente a la pena producto del aumento en bloque, a saber, presidio menor en su grado máximo a presidio mayor en su grado mínimo (la primera es una pena compuesta por un grado de pena, menor a la segunda, integrada por dos grados).

La comparación en abstracto no valida -como se pretende- un contrasentido de carácter valorativo, pues -al contrario de lo que se sostiene- el incremento en bloque no genera en sus consecuencias una equiparación punitiva de ambos supuestos, dado que un delito de robo por sorpresa con dos agravantes puede tener asignado tanto una pena mayor (presidio mayor en su grado mínimo) como también una pena menor (presidio menor en su grado máximo) a aquella correspondiente a dos delitos reiterados de robo por sorpresa sin agravantes respecto de los cuales el aumento propio de la reiteración se realice en bloque (presidio menor en su grado máximo a presidio mayor en su grado mínimo).

Descartada la equiparación de pena entre ambos supuestos, sólo en el primer caso - de otorgarse la máxima eficacia admisible a las agravantes- se verificaría, en principio, una suerte de dicotomía en el tratamiento penal de éstos, pues en ese evento la comisión de un solo delito con dos agravantes tendría asignada en abstracto una sanción mayor a la ejecución de dos delitos reiterados (aunque sin la presencia de agravantes, cuestión que, como se verá, no debe subestimarse reconduciéndola a un simple dato accidental); pero tal contradicción desaparece para el segundo caso posible -de otorgarse el mínimo efecto imperativo a las circunstancias agravantes-, escenario en el que la respuesta penal asignada a una pluralidad de delitos reiterados es sustancialmente superior (un grado de pena de diferencia) a la adscrita a la ejecución de uno solo de ellos con dos agravantes.

De todos modos, escenario que no advierte el autor, el mismo contrasentido valorativo que se denuncia también puede verificarse si se adopta el modelo de incremento a partir del grado máximo, modelo que defiende Oliver Calderón. Así, si en el ejemplo propuesto se aumentase en un grado el marco penal asociado a dos delitos reiterados de robo por sorpresa sin agravantes desde el grado máximo, se generará un marco penal de presidio mayor en su grado mínimo, que es exactamente el mismo marco asignado a un solo delito con dos agravantes, si es que se atribuye a dichas circunstancias su máxima eficacia discrecional admisible normativamente.

Dado que el contrasentido valorativo denunciado no se constata en todos los supuestos ni tampoco se genera como consecuencia derivada sólo del incremento en bloque, no puede pretenderse entonces su validez general ni ser atribuida, en su caso, solo a dicho modelo de aumento de grado.

La cuestión, en definitiva, no radica en la técnica que se adopte respecto del aumento en grado propio de la exasperación, sino que en la fragilidad del presupuesto que sostiene el argumento, a saber, la asunción invariable de que siempre dos delitos reiterados sin 


\section{BESIO, Martín. “Aplicación del artículo 351 del Código Procesal Penal”.}

agravantes importa un supuesto más grave -y que por ello merece más pena- que un solo delito con dos agravantes. Tal presupuesto no es para nada evidente ni se puede asumir sin más, dado el incremento relevante de desvalor de injusto que puede implicar incluso en abstracto la presencia de dos circunstancias agravantes de responsabilidad y que no siempre es -ni tiene por qué serlo- menor al representado por el desvalor asociado a dos delitos que se sancionan bajo un régimen especial cuyo objetivo es - no debe olvidarse- aminorar la pena de esa pluralidad delictiva, esto es, morigerar los efectos punitivos asociados precisamente a la reiteración de delitos (en rigor, del efecto punitivo asociado al segundo delito que genera la reiteración y que se compara con el desvalor representado por dos agravantes).

De hecho, extremando las posibilidades en abstracto e independientemente de la forma que adopte el aumento en grado, bajo el régimen de exasperación la comisión de -por ejemplotres delitos reiterados de robo por sorpresa, cada uno con tres agravantes de responsabilidad, puede conllevar la misma pena que la asignada a un solo delito de robo por sorpresa con dos agravantes, si es que a éstas se les otorga el mínimo efecto imperativo de exclusión del grado mínimo en el primer caso y el máximo efecto discrecional de aumento en grado en el segundo, a saber, la misma pena -para ambos supuestos delictivos- de presidio mayor en su grado mínimo; contrasentido valorativo (misma pena asignada a tres delitos con tres agravantes cada uno, que a un solo delito con dos agravantes) que en ese escenario no está condicionado por la forma en que se realice el aumento en un grado (toda vez que la aplicación primaria de los efectos de las agravantes concurrentes genera un marco penal compuesto por un grado de penalidad, sobre el que se realiza luego el incremento), sino que por los efectos privilegiados asociados normativamente al sistema de acumulación jurídica, lo que demuestra que el modelo de aumento en grado -en bloque o desde el grado máximo- no es determinante.

Asimismo, Oliver Calderón cuestiona las razones tradicionalmente esgrimidas por la doctrina para justificar la preferencia del sistema de aumento en bloque. Así, entre otras ideas, como la plausibilidad interpretativa de erigir al art. 68 del Código Penal como la regla general en materia de aumento de grado, cuestión que en todo caso no resulta decisiva, como el propio autor pareciera advertir" ${ }^{38}$; se sostiene que "(...) lo establecido en el art. 57 del Código Penal no impide entender que cuando el artículo 351 del Código Procesal Penal ordena aumentar la pena, lo hace pensando en imponer una superior a toda ella y no sólo a una de sus partes; de lo contrario, como lo he dicho, no se estaría exasperando" 39 , línea interpretativa -acerca de la intención del legislador al disponer el aumento en grado en la regla de reiteración- que, siendo posible, de todos modos resulta incompatible precisamente con el contenido del art. 57 del Código Penal, regla que al establecer la autonomía e independencia de cada grado de pena al interior del marco penal subraya -como consecuencia- la necesidad de que los efectos del aumento en grado se extiendan a todos ellos, lo que sólo es posible a través del incremento en bloque.

Además, debe replicarse que dicha forma de aumento sí supone una exasperación de pena, constituida precisamente por el incremento que se verifica respecto de cada uno de los

\footnotetext{
${ }^{38}$ Supra, nota $\mathrm{n}^{\circ} 32$.

${ }^{39}$ OLIVER CALDERÓN, "La exasperación”, cit. nota nº 9, p. 180.
} 
grados de pena que integran un marco compuesto; por lo que, como consecuencia del aumento en bloque, se genera una pena superior a la pena base (desde la óptica de la independencia de las penas que la componen). Por ello, no es efectivo que el incremento en bloque "(...) distorsiona el sistema de la exasperación, al permitir la aplicación de una pena que ya estaba comprendida dentro del marco penal disponible antes de efectuar el aumento" $" 40$, porque lo relevante para el sistema de exasperación es el incremento de un marco penal compuesto por dos o más penas, incremento que se verifica por medio del aumento en bloque a través - precisamente- del aumento de cada una de las penas que integran el marco penal; siendo indiferente - dada la individualidad y autonomía asignada a cada grado de penalidad- la cuestión accesoria de si dentro del marco aumentado se encuentra alguna pena del marco precedente, ya que dicha pena del marco precedente no es otra cosa que una pena ya incrementada en razón del sistema de exasperación.

\subsection{Sistema de cuantificación.}

La jurisprudencia suele operar bajo la premisa de que al interior del régimen de acumulación jurídica conviven dos modelos diferentes de cuantificación de la pena: uno para su inciso primero, en el que el incremento en grado de la reiteración se verifica con antelación a los efectos de las circunstancias que concurran; y otro para su inciso segundo, en el que las circunstancias adquieren preferencia en la depuración del marco penal primario $^{41}$.

Aunque no son evidentes las razones de tal interpretación, pues no es posible verificar en las sentencias un desarrollo argumental consistente del art. 351 del Código Procesal Penal, ésta se encuentra aparentemente condicionada por su inciso segundo, que prevé explícitamente un orden de cuantificación -que silencia su inciso primero- estructurado a partir de la aplicación primaria de las circunstancias para la construcción de la pena sobre la que posteriormente debe efectuarse el aumento derivado de la exasperación; de ahí que, aparentemente, a contrario sensu, se invierta el orden de convergencia para el supuesto reglado por el inciso primero, pese a las diferencias sustanciales de pena que en ciertos supuestos genera dicha dualidad.

Si es correcto que los incisos primero y segundo de la regla de exasperación contienen distintos regímenes de individualización, adquiere crucial importancia determinar entonces qué infracciones de la misma especie pueden ser consideradas como un solo delito (y por ello integrarse al inciso primero) y cuáles, de acuerdo a su naturaleza, no pueden serlo (adscribiéndose a su inciso segundo). Por contra, si ambos incisos se subordinan a la misma estructura de individualización o - de otra forma- si el sistema de cuantificación que prevé el inciso segundo se replica también para el inciso primero, la cuestión pierde toda relevancia práctica.

\footnotetext{
${ }^{40}$ OLIVER CALDERÓN, “La exasperación”, cit. nota n 9, p. 179.

41 También parecieran concebirlo así ORTIZ, Luis; ARÉVALO, Javier, Las Consecuencias Jurídicas del delito, Santiago: Editorial Jurídica, 2013, p. 340 [cit: Consecuencias]; en tanto al referirse al régimen del inciso segundo, que impone la consideración preferente de las circunstancias modificatorias, sostienen que en el caso del inciso primero la pena base del cálculo se determina en abstracto ("en la hipótesis anterior se consideraba la penalidad en abstracto").
} 


\section{BESIO, Martín. “Aplicación del artículo 351 del Código Procesal Penal”.}

En ese escenario, existen diversas aproximaciones. La postura tradicional ha entendido que se integran al inciso primero $-\mathrm{y}$ pueden estimarse como un solo delito- aquellas infracciones que pueden ser medidas en magnitudes o cuya caracterización y pena se estructura a partir de dimensiones acumulables susceptibles de adición (por ejemplo, estafas, hurtos y daños), determinándose la pena a su respecto a través de la sanción que comprenda la suma de todas las magnitudes asociadas a todos los delitos, para luego proceder al aumento en grado ${ }^{42}$. El inciso segundo, por otra parte, estaría destinado a reglar la convergencia de los restantes delitos, a saber, de aquellos que no se rigen por el inciso primero.

Esta postura ha sido cuestionada -con razón- por un sector creciente de la doctrina, que ha puesto de manifiesto los inconvenientes que presenta ${ }^{43}$. Por una parte, porque supone un tratamiento más perjudicial para aquellos delitos que se adscriben al inciso primero en comparación con aquellos integrados al inciso segundo, en un escenario normativo en que, salvo antecedentes históricos asociados a la figura análoga prevista en la antigua legislación procesal penal, de discutible extensión y efecto vinculante a la actual ${ }^{44}$, el contenido del art. 351 del Código Procesal Penal no circunscribe -al menos no explícitamente- la aplicación del inciso primero sólo a aquellas infracciones en que la pena se construye a partir de cuantías económicas.

El tratamiento perjudicial se verificaría -en el inciso primero- al sumar los importes asociados a los delitos reiterados para la determinación de la pena base del régimen de exasperación, pena de un delito no ejecutado y construido artificialmente para estos efectos; escenario que no se produce en el caso del inciso segundo, pues al alero de éste la pena base del cálculo es la pena de un delito real y efectivamente cometido (a saber: el delito que conlleva una pena mayor), no influyendo entonces en la cuantificación la pena asociada a los restantes delitos que integran la reiteración.

42 NOVOA MONREAL, Curso, cit. nota ${ }^{\circ}$ 30, p. 227, aunque respecto del art. 509 del Código de Procedimiento Penal, idéntico en este punto al art. 351 del Código Procesal Penal; también a propósito de la primera norma, ETCHEBERRY, Derecho penal, cit. nota ${ }^{\circ} 26$, p. 117, aunque tácitamente al agregar, luego de sostener que deben tener un carácter homogéneo y concebirse idealmente como un solo delito, que "[e]l caso característico es el de aquellos en que la penalidad se determina por la cuantía o monto (de lo hurtado, de lo estafado, de lo malversado, etc.)"; recientemente respecto del art. 351 del Código Procesal Penal, POLITOFF/MATUS/RAMÍREZ, Lecciones, cit. nota $n^{\circ} 6$, p. 467, adhiriéndose expresamente a la posición y con la respectiva cita- de Novoa Monreal.

${ }^{43}$ SOLARI/RODRÍGUEZ, "Determinación”, cit. nota n 2, p. 266 y ss., respecto del art. 509 del Código de Procedimiento Penal. Actualmente, tratándose de la nueva regla de reiteración, COUSO SALAS, “Comentario previo", cit. nota n 7, pp. 650-651; y OLIVER CALDERÓN, "La exasperación”, cit. nota n 9, pp. 173 y ss.; cuyos argumentos comparto, con los matices que se exponen infra.

${ }^{44} \mathrm{El}$ antecedente histórico se encuentra en la Sesión $21^{\circ}$ de la Comisión revisora del proyecto de Código de Procedimiento Penal, en la intervención del senador Valdés respecto de la regla origen del art. 509 del Código de Procedimiento Penal; no obstante lo cual, como concluye -con razón- OLIVER CALDERÓN, "La exasperación”, cit. nota $\mathrm{n}^{\circ} 9$, p. 174, quien incorpora la cita respectiva, “(...) no puede dejar de considerarse que la voluntad de los miembros de aquella comisión se manifestó respecto de una ley distinta del Código Procesal Penal (¡dictada un siglo antes $;$ ) y de un precepto de contenido diferente al del artículo 351 CPP, por lo que no resulta decisiva". 


\section{Polít. crim. Vol. 10, № 20 (Diciembre 2015), Art. 5, pp. 543-596. \\ [http://www.politicacriminal.cl/Vol_10/n_20/Vol10N20A5.pdf]}

Se sostiene, asimismo, que dicha regulación diferenciada supondría para los delitos incorporados al inciso primero una doble valoración de una misma circunstancia con efectos agravatorios de pena (una vulneración del principio non bis in ídem), bajo el argumento que el número de los delitos sería objeto de ponderación tanto para la determinación de la pena base del cálculo como para -posteriormente- la decisión respecto del número de grados en que ésta se aumentará ${ }^{45}$. Dicho argumento, con todo, no resulta decisivo, puesto que la valoración del número de infracciones para los efectos del aumento en grado -su segunda valoración- sólo será perjudicial para el condenado si es que -en razón de su número- se decide efectivamente el incremento en un segundo grado (toda vez que el aumento en al menos un grado es imperativo), pero no influirá en una mayor asignación de pena -esto es, la segunda valoración del número de infracciones no será perjudicial $^{46}$ - si el número de los delitos concurrentes es ponderado como proporcionado a un solo grado de incremento y no de dos; por lo que entonces la vulneración a la prohibición de doble valoración sólo podría esgrimirse en el caso concreto y únicamente para el evento en que el tribunal, atendido el número de delitos, decida otorgar en razón de dicho número la máxima agravación discrecional posible de la exasperación.

Al margen de ello, la doble ponderación que se advierte es sólo parcial y tangencial, aun cuando pueda aceptarse que de todos modos constituye una doble valoración de una misma circunstancia (siempre que se decida en el caso concreto el aumento de un segundo grado), ya que lo determinante en términos de asignación de una mayor pena para aquellas infracciones que pueden estimarse como un solo delito es la ponderación para el cálculo de pena de -precisamente- cada una de las penas asociadas a tales infracciones y que se suman para la construcción de una nueva sanción ficticia (procedimiento injustificado con respecto a aquellos delitos del inciso segundo), ponderación en la que la consideración aislada del número de delitos es sólo indirecta, pues proviene como una consecuencia inevitable de las penas que se adicionan.

Por último, esta tesis tradicional supone una aplicación analógica -en perjuicio del condenado y por ello analogía prohibida- de la regla de cuantificación del art. 451 del Código Penal, que prevé para los efectos de individualización de la pena de un supuesto específico de concurso real de delitos de una misma especie (reiteración de hurtos), la fórmula de tomar por base el importe total de los objetos sustraídos, más un incremento al grado superior ${ }^{47}$.

\footnotetext{
45 Así, OLIVER CALDERÓN, "La exasperación”, cit. nota $n^{\circ}$ 9, p. 173: “(...) implica vulnerar el principio non bis in idem, al considerar en dos ocasiones un mismo hecho en un sentido perjudicial para el imputado. En efecto, esta interpretación obliga, cuando se trata, por ejemplo, de varios delitos de hurto, a tomar en cuenta todas las infracciones para determinar un marco penal (al sumar las cuantías involucradas en cada uno de los delitos, inevitablemente se está considerando la totalidad de las infracciones), y luego, nuevamente, el número de los delitos concurrentes para precisar el número de grados en que se aumentará la pena".

46 Siendo, en rigor, la primera consideración del número de delitos una valoración en beneficio del condenado, pues es precisamente esa ponderación numérica (que exista más de un delito de una misma especie en concurso real) la que permite su inclusión en el régimen -más favorable como regla general- del art. 351 del Código Procesal Penal.

${ }^{47}$ GARRIDO MONTT, Mario, Derecho Penal, parte general, t. II, $3^{\circ}$ ed., Santiago: Editorial Jurídica, 2003, p. 346, n. 687; OLIVER CALDERÓN, “La exasperación”, cit. nota n 9, pp. 173-174.
} 


\section{BESIO, Martín. “Aplicación del artículo 351 del Código Procesal Penal”.}

Descartada dicha aproximación, el problema tiende a desaparecer si se acepta que para las infracciones del inciso primero rige el mismo sistema que prevé el inciso segundo, conclusión que resulta obligada desde un prisma teleológico si se asume que no existe razón que justifique un tratamiento diferenciado para ambas clases de delitos de una misma especie, puedan o no puedan estimarse como un solo delito de acuerdo a su naturaleza ${ }^{48}$, a menos que pueda fundarse adecuadamente la atribución de un régimen punitivo más gravoso para ilícitos de una misma especie que pueden ser estimados como un solo delito respecto de aquellos ilícitos -también de una misma especie- cuya naturaleza impida su unificación para efectos de la reiteración.

Para ambos incisos el procedimiento de individualización es el mismo, a saber, supone establecer la pena del delito - de entre aquellos de una misma especie- que con las circunstancias del caso sea mayor, para luego proceder al aumento en uno o dos grados conforme al número de infracciones que integran la reiteración ${ }^{49}{ }^{50}$.

De todos modos, y aunque sea una cuestión meramente nominal, sobre la base de que rige para ambos incisos el mismo sistema de individualización, la única interpretación viable del inciso primero radica en entender que constituyen infracciones que pueden ser estimadas como un solo delito aquellas que -siendo de la misma especie, configuren o no el mismo tipo de delito- tienen la misma pena en concreto, una vez depurada la sanción abstracta asignada a cada infracción conforme a sus respectivas circunstancias; expresión normativa

\footnotetext{
${ }^{48}$ Con razón concluye COUSO SALAS, “Comentario previo”, cit. nota ${ }^{\circ} 7$, pp. 650-651, una vez asentado que el objetivo del sistema de acumulación jurídica es moderar los excesos punitivos derivados de la acumulación material, que “(...) este objetivo se justifica con la misma razón para los dos grupos de delitos a los que se refiere la disposición -los que pueden considerarse como un solo delito y los que, por su naturaleza no pueden considerarse de ese modo- (...)"; también, en la misma línea, OLIVER CALDERÓN, "La exasperación", cit. nota $\mathrm{n}^{\circ}$ 9, pp. 275 y ss.; y con antelación, pero respecto del art. 509 del Código de Procedimiento Penal, SOLARI/RODRÍGUEZ, "Determinación", cit. nota $\mathrm{n}^{\circ}$ 2, p. 265; todos quienes defienden la interpretación que -en general- se acoge en el texto, con las precisiones y matices que se exponen.

${ }^{49}$ Criterio -el número de delitos- que, cabría agregar, no obstante sólo se encuentra previsto para los delitos del inciso segundo, de todos modos se ha extendido sin problema para aquellos del inciso primero (así, NOVOA MONREAL, Curso, cit. nota n 30, p. 229, n. 9: “(...) aun cuando se haya omitido expresarlo”), lo que refuerza la plausibilidad de extender también el sistema de cuantificación previsto para aquellos a estos últimos.

${ }^{50}$ MATUS ACUÑA, "Proposiciones", cit. nota $n^{\circ}$ 1, p. 537, n. 33, ha intentado justificar dicho orden para los delitos del inciso segundo bajo la idea de que sólo tal homologación permitiría una adecuada comparación entre los sistemas de acumulación jurídica y acumulación material para los efectos de decidir la aplicación subsidiaria del primero; así, “(...) elevar la pena a partir del marco establecido en el tipo penal, impide una adecuada comparación de este sistema con las reglas del art. $74 \mathrm{CP}$, cuando se requiere establecer cuál de ellos supone una «pena menor», pues se estarían comparando penas abstractas con concretas, lo que fuerza un poco la lógica y hace perder el sentido del art. 351, que es ofrecer un sistema penológico más benigno que el de la regla general", argumento que no convence del todo, porque nada impide que incluso realizando el aumento propio de la reiteración a partir del marco penal abstracto para luego proceder a la aplicación de las circunstancias que concurran, de todas formas la comparación con las penas resultantes del régimen de acumulación material se realice considerando las penas concretas determinadas en conformidad con ambos sistemas, a menos que el presupuesto base de dicho argumento sea la posibilidad de comparación de la pena (marco penal) resultado del aumento de la exasperación sin los efectos de las circunstancias, por una parte, con las penas determinadas de acuerdo al art. 74 del Código Penal, por la otra, comparación que, se advertirá, no es obligada ni resulta sostenible precisamente en virtud de las razones que expone el autor.
} 
que no sólo refiere a las circunstancias modificatorias propiamente tales (atenuantes y/o agravantes) que puedan concurrir, sino que también -en tanto inciden en la cuantificación de la pena- a las fases de ejecución delictiva y, en su caso, a las clases de intervención criminal que puedan presentarse respecto de cada una de ellas. Asimismo, no pueden ser consideradas como un solo delito, adscribiéndose a su inciso segundo, las infracciones restantes, a saber, aquellas que siendo de la misma especie presentan diferentes penas en concreto, ya sea porque no configuran el mismo tipo de delito, ya sea porque configurándolo sus circunstancias (atenuantes y/o agravantes, formas de imperfecta ejecución y/o intervención criminal) generan una diferencia punitiva entre ellas.

Aunque la doctrina suele entender la expresión normativa circunstancias del inciso segundo del art. 351 del Código Procesal Penal como indicativa de circunstancias modificatorias de responsabilidad ${ }^{51}$, es evidente que no sólo éstas inciden en la pena concreta que sirve de base al cálculo -y respecto de la que se realiza el respectivo aumento en grado-, sino que también influyen, en su caso, los estadios de ejecución en que se presente el delito y la forma que adopte la intervención del condenado en el mismo, escenario que desde ya genera la necesidad y plausibilidad de incluir a todos estos factores en dicha expresión. Además, el término circunstancias no constituye un concepto técnico de significado jurídico-penal unívoco (como sí lo sería, por ejemplo, las expresiones circunstancias modificatorias o circunstancias atenuantes y agravantes); alude simplemente, en su sentido natural, a las particularidades o características del delito que -al interior del sistema de exasperación- sean relevantes para la individualización de la pena (circunstancias del caso).

La interpretación que se propone es consistente con el texto legal, ya que una pluralidad de delitos de una misma especie en relación de concurso real que comparten una misma pena en concreto es el único supuesto (al margen de la reiteración de exactamente el mismo tipo penal) en materia de individualización de la pena en que dicha pluralidad es susceptible de ser estimada normativamente como si fuese un solo delito; lo que justifica, entonces, a partir precisamente de esa pena concreta realizar el incremento en grado derivado de la exasperación. Esto, a diferencia de aquellas infracciones que no comparten una misma pena en concreto, supuesto paradigmático de una pluralidad delictiva que no puede -por definición- ser estimada como si fuera un solo delito y que genera la necesidad de dilucidar un procedimiento equivalente para los efectos de su cuantificación al interior del sistema de acumulación jurídica.

Ello explica en el inciso primero la ausencia de un orden explícito de cuantificación que sí provee el inciso segundo, ya que en tanto las infracciones que se adscriben a aquél pueden ser estimadas como un solo delito porque tienen la misma pena en concreto, no resulta necesario entonces consagrar y repetir el mismo orden establecido para aquellas que no pueden ser estimadas como una unidad (porque tienen diferentes penas en concreto), dado que la pena base para el cálculo al interior del régimen de exasperación (la pena mayor) puede ser cualquiera de las penas de cualquiera de los delitos que se entienden como uno, ya que la pena es la misma.

${ }^{51}$ Así, entre otros, OLIVER CALDERÓN, "La exasperación”, cit. nota $n^{\circ}$ 9, p. 175; CONTRERAS GUERRERO, "Una tesis", cit. nota n 4, p. 656. 


\section{BESIO, Martín. “Aplicación del artículo 351 del Código Procesal Penal”.}

La cuestión, entonces, acerca de la naturaleza unitaria de las infracciones pierde toda utilidad $^{52}$, pasando a primer plano la determinación del presupuesto central bajo el que una pluralidad de delitos en relación de concurso real puede ser considerada de una misma especie, a saber, la unidad de bien jurídico, pues esta definición previa es la que condiciona su inclusión en el régimen de reiteración, ya sea a través de su adscripción a su inciso primero, ya sea al alero de su inciso segundo.

En tal escenario, adquiere relevancia el objetivo asumido por el sistema de acumulación jurídica, orientado a la atenuación de los efectos -eventualmente excesivos- que podrían derivarse del sistema de acumulación material de las penas, objetivo que subraya la conveniencia de interpretar extensivamente el concepto de unidad de bien jurídico en términos de maximizar la capacidad de rendimiento práctico del sistema de reiteración, integrando a su alero no sólo a aquellos ilícitos que tutelan el mismo bien jurídico (coincidencia total), sino que también a aquellas infracciones que compartan al menos un mismo o similar bien jurídico como objeto de protección (coincidencia parcial), eliminado al mismo tiempo las trabas extranormativas que limitan su aplicación, como la exigencia adicional -reivindicada por un sector de la doctrina- asociada a la misma o similar forma que adopta el ataque ${ }^{53}$.

En suma, toda vez que la finalidad de la regla de reiteración de delitos de una misma especie consiste en morigerar la asignación de la mayor cantidad de pena que cabría atribuir primariamente por medio del sistema de acumulación material (cometido ratificado por la aplicación preferente de este último en caso de que tal atenuación no se produzca), y dado que tal finalidad -derivada de la idea de humanidad de las penas ${ }^{54}$ - se presenta respecto de todos los delitos que se presentan en relación de concurso real, coincidan total o parcialmente en la protección de un mismo o similar bien jurídico ${ }^{55}$, los efectos del sistema de acumulación jurídica debiesen en consecuencia alcanzar a todos, pues en todos ellos se replica la misma necesidad de atenuación de la respuesta penal.

\subsection{Marcos integrados por un grado de pena, con una circunstancia modificatoria.}

El orden integrado al sistema de cuantificación del art. 351 del Código Procesal Penal genera una aparente inconsistencia sistémica que se presenta en el supuesto en que la pena mayor que sirve como base del cálculo está constituida por un marco compuesto por un grado de penalidad y concurra al mismo tiempo una circunstancia modificatoria, sea atenuante o agravante. La inconsistencia se verifica en tanto los efectos de dicha circunstancia, limitados exclusivamente al interior del marco penal, pierden toda influencia en la pena resultante como consecuencia de su aplicación preferente respecto del aumento

\footnotetext{
${ }^{52}$ COUSO SALAS, "Comentario previo", cit. nota n ${ }^{\circ}$ 7, pp. 652-653.

${ }^{53}$ Exigencia adicional sin sustento en el art. 351 del Código Procesal Penal invocada por CURY URZÚA, Derecho penal, cit. nota ${ }^{\circ} 7$, pp. 661-662, n. 42 y p. 512, por extensión derivada de la regla de reincidencia propia específica (art. $12.16^{\circ}$ del Código Penal).

${ }^{54}$ MATUS ACUÑA, "Proposiciones", cit. nota $n^{\circ}$ 7, p. 529, advierte, en esa línea, que “(...) en la aplicación práctica de la regla del art. $351 \mathrm{CPP}$ (como así también sucede respecto de la del art. $75 \mathrm{CP}$ ), lo que predomina son consideraciones de carácter puramente contingente y humanitario (...)".

${ }_{55}$ Necesidad que se verifica incluso respecto de aquellos delitos en concurso real que no comparten el mismo objeto de tutela, aunque ello no se haya rescatado positivamente.
} 
en grado derivado de la reiteración, ya que éste se materializa con independencia y sin considerar los efectos ya producidos por la circunstancia concurrente.

Así, por ejemplo, tratándose de una reiteración de delitos con una atenuante, en que la pena mayor en abstracto esté constituida por un marco penal de presidio menor en su grado medio, la aplicación primaria de la atenuante -en razón del art. 67 del Código Penalemplazará el marco provisional en su mínimum, para luego realizarse el aumento, por ejemplo, en un grado, generándose un nuevo marco de presidio menor en su grado máximo en toda su extensión. Los efectos de la atenuante se neutralizan en la medida que el aumento en grado - por definición- opera respecto de todo el grado de penalidad y no a partir del mínimum del marco incrementado. Lo mismo ocurre si se presenta solo una agravante, que fijará provisionalmente el marco en su máximum, efecto de depuración del marco penal que desaparece con posterioridad al incremento en grado, que situará el marco concreto en toda la extensión de presidio menor en su grado máximo.

La pregunta que cabría formular es si el sistema de cuantificación permite que efectos agravatorios o atenuatorios de pena -que suponen alteraciones relevantes del injusto del hecho o de la culpabilidad del autor- no tengan un reflejo adecuado en la sanción resultante; o, de otra forma, cabría preguntarse cómo evitar que dichos efectos sean neutralizados por las propias reglas del sistema de determinación y, en definitiva, cómo otorgarles una vía de incidencia proporcionada en la cuantía de pena.

En la dogmática de individualización de la pena se recurre a la categoría de los déficit marginales de pena para referir a aquellos contextos normativos en que factores relevantes para la cuantificación de la pena no son reconducidos al interior del marco penal, normalmente porque el legislador no les ha atribuido un efecto de forma explícita de aumento o disminución de la sanción; pero que no obstante engloba -esta categoría- todos aquellos supuestos en que por alguna razón se "pierde" pena que debería ser considerada e incluida en la respuesta penal. El supuesto paradigmático se encuentra en el caso de los tipos mixtos alternativos, como la figura de homicidio calificado, en que las calificantes carecen de autonomía individual para la asignación en abstracto de una mayor cantidad de pena pese a que cada una por sí sola supone un incremento relevante del injusto del hecho, pues verificándose una de ellas, que posibilita la configuración del tipo calificado, las restantes resultan irrelevantes al efecto. La idea general detrás de rescatar los déficit marginales de pena, otorgándoles un reflejo adecuando en la sanción, es, en este caso, “(...) evitar que a mayor gravedad no corresponda mayor pena, con el consiguiente déficit de pena, [por lo que] en la medida en que el hecho revista una mayor gravedad en atención a la plural concurrencia de elementos de agravación o de hechos la medición de la pena debe valorar adecuadamente esas circunstancias" $" 56$.

\footnotetext{
${ }^{56}$ CHOCLÁN MONTALVO, José Antonio, Individualización judicial de la pena. Función de la culpabilidad y la prevención en la determinación de la sanción penal, Madrid: Ed. Colex, 1997, p. 182. Respecto de la categoría de los déficit marginales de pena en la dogmática española, BESIO HERNÁNDEZ, Martín, Los criterios legales y judiciales de individualización de la pena, Valencia: Ed. Tirant lo Blanch, 2011, pp. 397 y ss. [cit.: Criterios].
} 
BESIO, Martín. “Aplicación del artículo 351 del Código Procesal Penal”.

Aunque se trata de una categoría con un todavía incipiente desarrollo, existe acuerdo en que la reconducción normativa de dichos déficit se materializa a través de la decisión cuantitativa de pena ${ }^{57}$, esto es, en la fijación de la cuantía exacta de sanción, escenario que constituye el momento y el soporte normativo idóneo para su recepción. Ello es especialmente evidente en el sistema penal chileno, en tanto el art. 69 del Código Penal contempla explícitamente como factor de medición punitiva al número y entidad de las circunstancias agravantes y atenuantes, por lo que al interior del régimen de reiteración la atenuante o agravante neutralizada por el posterior incremento en grado deberá ser estimada como una razón relevante de disminución o de aumento de la cuantía de pena, relevante en razón de su entidad en el caso concreto, que se encuentra determinada por su nula influencia al interior del régimen de exasperación y que -dependiendo del caso- podría incluso adoptar una incidencia mayor a la que tiene asignada positivamente cada circunstancia en la depuración previa del marco penal.

\subsection{El aumento potestativo del segundo grado.}

Existe consenso dogmático y jurisprudencial en que el régimen de reiteración supone el aumento imperativo en un grado y facultativo en dos grados, decisión discrecional -la del segundo grado- subordinada al baremo previsto al efecto en el inciso segundo del art. 351 del Código Procesal Penal y que se entiende aplicable a su inciso primero, a saber, de acuerdo al número de los delitos que integran la reiteración ${ }^{58}$.

No obstante se trata de un parámetro estrictamente objetivo cuya orientación pareciera ser evidente (a mayor cantidad de delitos existirán mayores razones para decidir el aumento en un segundo grado) ${ }^{59}$, en la práctica, en ausencia de estándares más precisos la decisión que se adopta a su alero suele estar subordinada en las sentencias a la subjetividad del tribunal, tornándose en aleatoria -si no en arbitraria- a falta de motivos que la justifiquen.

Es posible, en todo caso, una aproximación dogmática al problema, construida sobre la base de la propia estructura normativa del art. 351 del Código Procesal Penal, que puede contribuir a la generación de un estándar algo más certero.

\footnotetext{
${ }^{57}$ Así lo admite la doctrina chilena respecto del concurso de calificantes en el homicidio calificado; por todos, MATUS, Jean Pierre; RAMÍREZ, M. Cecilia, Lecciones de Derecho Penal chileno, parte especial, Santiago: Ed. Legal Publishing, 2014, pp. 61-62.

${ }^{58}$ Se apartan de dicho consenso ORTIZ/ARÉVALO, Consecuencias, cit. nota ${ }^{\circ} 41$, p. 340, admitiendo la posibilidad de aplicar dicho baremo - previsto en el inciso segundo- de forma analógica a los delitos del inciso primero y advirtiendo que el mismo "(...) podría tropezar frente a situaciones en las cuales se cometa más de dos delitos", sin precisar no obstante el fundamento de tal dificultad, además de inclinarse, en desmedro del número de delitos, por “(...) un sistema de aumento de penalidad bajo un criterio valorativo amparado en la culpabilidad y por el injusto, criterio que permitiría al sentenciador, excluyendo parámetros meramente aritméticos, buscar la pena que más se avenga con la totalidad de los delitos cometidos por el delincuente", afirmación con la que -en principio- se podría estar de acuerdo, pero que dado su contenido genérico y a falta de criterios precisos que lo aterricen, deviene, a fin de cuentas, en nada más que una declaración de principios sin utilidad práctica.

${ }_{59}$ Así, NOVOA MONREAL, Curso, cit. nota n 30, p. 227, pues -en su opinión- “(...) otra cosa sería burlar la voluntad legislativa".
} 
La primera referencia es obvia: dado que para que exista reiteración de delitos se requiere de una pluralidad de ellos (de más de un delito) y toda vez que el mínimo incremento es en un grado, la sola concurrencia de dos delitos ya determina el aumento obligatorio de un grado. De ello se deriva, entonces, que dos delitos no pueden generar la posibilidad de aumento en un segundo grado, puesto que constituyen el mínimo necesario para la existencia de reiteración y, por ello, condicionan desde ya el aumento mínimo imperativo de un grado. En consecuencia, la facultad judicial de incremento en dos grados se genera sólo a partir de la existencia de un tercer delito.

Asimismo, el (mayor) número de delitos que componen la pluralidad no implica un incremento del desvalor de cada uno de los delitos que integran la reiteración, sólo supone - a mayor número de ellos, a partir del tercer delito- una mayor necesidad potencial de recurrir al aumento discrecional de un segundo grado, esto es, implica solo una posibilidad mayor de pena en razón de la reiteración. Ello, en tanto el segundo y tercer delito (y el cuarto y así en adelante) no son más graves por definición que el primer delito o delito base, ya que éste -que sirve de plataforma del cálculo de pena- es necesariamente el delito que tiene asignada una pena mayor, por lo que los restantes ilícitos serán de la misma gravedad que el primero (si tienen la misma pena en concreto) o de menor gravedad que éste ( si su pena en concreto es menor), pero nunca serán más graves (por definición no tendrán asignada una pena mayor).

Por otra parte, toda vez que el baremo previsto para el aumento discrecional del segundo grado constituye un criterio objetivo vinculado exclusivamente a la cantidad de delitos concurrentes, el valor de cada uno de ellos (a partir del segundo delito en adelante) para los efectos de dicha decisión de aumento es necesariamente equivalente, en tanto su ponderación en ese contexto se reduce únicamente a su concurrencia como unidad delictiva, esto es, como delito que se adiciona al resto de los delitos y cuya sumatoria -su número total- preside la decisión de aumento en el segundo grado. Lo relevante, en definitiva, para el aumento en un segundo grado es el número de delitos y no sus penas u otras particularidades, y en esa valoración objetiva todos los delitos -en tanto unidad que se adiciona al resto- tienen el mismo valor unitario.

Sobre la base de estas constataciones es posible determinar objetivamente el valor punitivo que representa cada delito que potencialmente puede contribuir al aumento en un segundo grado, esto es, el valor que importa en el caso concreto cada infracción adicional al segundo delito (tercer delito en adelante) que se adscribe a la reiteración, para luego proyectarlo sobre la pena mínima posible que supone un segundo grado de incremento a fin de evaluar -a través de una comparación entre los valores que cada delito adicional imprime a la reiteración y la pena mínima que importa el incremento- la procedencia proporcional de dicho aumento.

Un ejemplo puede clarificar las cosas. Piénsese en una reiteración de delitos de una misma especie en que la pena mayor está constituida por un marco concreto de presidio menor en su grado máximo, pena asignada al delito base del cálculo y que constituye el primer delito en tanto a su respecto opera todo el régimen de exasperación. A partir de dicha pena corresponde el aumento obligatorio de un grado, incremento que está determinado por la 


\section{BESIO, Martín. “Aplicación del artículo 351 del Código Procesal Penal”.}

sola presencia de un segundo delito (cualquiera de ellos, diferente al primero), generándose en su virtud un marco penal superior de presidio mayor en su grado mínimo. Dado que el segundo delito ha determinado por sí solo el aumento en dicho grado, su valor punitivo en este caso concreto, que corresponde a su incidencia sobre el marco base, es toda la extensión de dicho grado superior, esto es, toda la carga punitiva que supone la pena de presidio mayor en su grado mínimo (grado añadido a la reiteración en su virtud) y que puede ser traducida - en tanto pena- en una unidad cuantitativa asociada a su extensión, a saber, 1.824 días (que corresponde a la extensión que oscila entre el límite inferior de dicho grado, cinco años y un día; y su límite superior, diez años). El segundo delito, entonces, tiene -en este caso concreto- un valor punitivo de D1824 (donde D alude a la unidad de medición día). Por otra parte, el tercer delito supone al interior del régimen de reiteración el mismo valor punitivo que el segundo delito, puesto que el criterio establecido normativamente para los efectos de la decisión discrecional de aumento en un segundo grado refiere solo al número (a la cantidad) de las infracciones que integran la pluralidad; baremo cuya orientación se encuentra vinculada con la sumatoria de todos ellos en tanto unidades delictivas, esto es, a mayor número de delitos se verifica una posibilidad mayor de aumento en el segundo grado. El valor punitivo del tercer delito, entonces, también es de D1824.

Ahora bien, como el baremo del número de delitos opera en términos progresivos (a mayor número de infracciones, mayor posibilidad de aumento en un segundo grado), la presencia del tercer delito debe evaluarse conjuntamente con el segundo delito a fin de establecer la carga punitiva que genera aquél en la reiteración al adicionarse a la pluralidad de infracciones. Así, el tercer delito imprime a la reiteración una carga punitiva de D3.648, resultante de sumar los valores del segundo y tercer delito. Lo relevante, llegados a este punto, es comparar dicho valor global con el que representa un eventual aumento en un segundo grado, importe este último que está constituido al menos por la carga punitiva asociada al límite inferior del marco penal superior en un segundo grado, esto es, por la pena mínima posible de presidio mayor en su grado medio: por diez años y un día o por el valor D5.476. Dicha comparación deviene en necesaria por la sencilla razón de que refleja una proyección de la pena mínima que implica para el caso concreto el aumento en un segundo grado. Pues bien, en el ejemplo, la presencia del tercer delito supone para la reiteración una carga punitiva de D3.648, inferior al valor mínimo posible que importa el aumento en un segundo grado (D5.476), de lo que se deriva que tal incremento deviene en improcedente tratándose del tercer delito en tanto la carga punitiva que éste genera para la reiteración de infracciones es inferior a la producida por el aumento en un segundo grado, resultando, en definitiva, desproporcionado; o, en otras palabras, el valor punitivo que adiciona el tercer delito a la reiteración es menor a la pena de dicha reiteración aumentada en un segundo grado, por lo que tal aumento no es cubierto desde una óptica punitiva por el tercer ilícito.

En la misma secuencia, el cuarto delito supone un valor de D1824 (equivalente al del segundo y tercer delito), generando en la reiteración, al adicionarse a la carga punitiva ya introducida por el delito antecesor, un valor global de D5.472, que es inferior al representado por la pena mínima posible asociada a la decisión de aumento en un segundo grado (D5.476); por lo que en presencia del cuarto delito tal aumento no resulta consistente con el valor asociado a la reiteración. Sólo a partir del quinto delito, que introduce en la 
reiteración una carga punitiva superior a la pena generada para la reiteración por el segundo grado de incremento (un valor global de D7.296 en comparación a D5.476 derivado del aumento) deviene en procedente la exasperación en un segundo grado.

En un escenario como el propuesto, si bien la decisión discrecional de aumento en un segundo grado existe potencialmente a partir del tercer delito integrado a la pluralidad, sólo resulta adecuada su materialización en presencia del quinto delito. Tal conclusión, por cierto, no es susceptible de una extensión general, ya que se encuentra condicionada por las particularidades del caso - por los marcos penales en juego-, no obstante el proceso de análisis comparativo es el mismo para todos los supuestos.

De todos modos, el sistema de comparación proyectiva supone como presupuesto que es posible determinar el número de delitos que integran la reiteración, lo que no siempre es factible al interior del proceso penal ni tampoco -cabría agregar- es indispensable para los efectos de la aplicación del art. 351 del Código Procesal Penal, pues aunque no sea posible dilucidar el número exacto de infracciones que la componen basta con que exista evidencia suficiente acerca de la existencia de una pluralidad delictiva -de que se ha cometido más de un delito de una misma especie- para que ésta pueda subordinarse al régimen de reiteración. En ese caso, no obstante, sólo podrá procederse al aumento mínimo imperativo de un grado, quedando vedado el recurso discrecional al segundo grado superior.

En suma, el incremento potestativo en un segundo grado se encuentra sujeto a una limitación de carácter interna, derivada de la propia estructura del art. 351 del Código Procesal Penal. Sólo procede - por razones de proporcionalidad- el aumento potestativo en dos grados si la carga punitiva que el número de delitos imprime a la reiteración es superior a la pena mínima posible que genera para ésta dicho aumento.

Al mismo tiempo, la decisión de aumento en un segundo grado está condicionada por una restricción externa, vinculada a la aplicación subsidiaria del art. 74 del Código Penal. Dado que el sistema de acumulación jurídica es un sistema privilegiado respecto del régimen de acumulación material, de resultar más gravoso para el condenado que este último se excluye su operatividad. De ello se deriva una segunda limitación que se extiende no sólo al aumento imperativo en un grado sino que también al aumento potestativo en un segundo grado, pero que opera una vez que el tribunal ha decidido efectivamente implementar dicho incremento facultativo: si la pena única a imponer derivada del aumento en dos grados constituye una pena superior a las penas individualizadas conforme al régimen de acumulación material, deberán imponerse estas últimas.

\subsection{Subsidiariedad del régimen de acumulación material.}

Entre el régimen de acumulación material y el régimen de reiteración se verifica una relación de doble vía, pues mientras éste goza de preferencia dada su especialidad respecto del primero, especialidad determinada por la identidad del bien jurídico tutelado por los delitos que se integran bajo su alero, aquél se presenta al mismo tiempo como el sistema 


\section{BESIO, Martín. “Aplicación del artículo 351 del Código Procesal Penal”.}

subsidiario al que debe retornarse siempre $^{60}$ que por su intermedio sea posible la imposición de una pena menor, conforme lo prevé el inciso tercero del art. 351 del Código Procesal Penal.

La expresión normativa pena menor, que condiciona la exclusión del régimen de exasperación, debe ser objeto de algunas precisiones.

En primer lugar, pese a su configuración singular dicho término no refiere a una unidad de pena como objeto de comparación, esto es, a una sola pena, sino que a una valoración global de la carga punitiva que supone para el condenado el régimen de acumulación material, que implica la imposición de más de una pena en comparación con la pena única que se extrae del sistema de exasperación. En tanto el resultado que ofrece el régimen del art. 74 del Código Penal es siempre la imposición de más de una pena, por contra de la pena única que genera el art. 351 del Código Procesal Penal, la comparación entre ambos sistemas no atiende al número de penas que se extraen de uno y otro (si así fuese, el sistema de acumulación material sería inaplicable como respuesta subsidiaria al sistema de reiteración), sino que a la intensidad punitiva de la respuesta penal -unitaria o plural-que importa cada cual.

En segundo término, se presenta el problema de determinar los criterios bajo los cuales se pondera la intensidad punitiva que suponen ambos regímenes.

La doctrina se encuentra dividida entre un criterio estrictamente cuantitativo, orientado a mensurar la extensión de las penas resultantes en concreto (baremo conforme al cual debe sumarse la duración o cuantía de las penas concretas del sistema de acumulación material y dicho resultado debe compararse con la extensión de la pena derivada de su acumulación jurídica), excluyendo la posibilidad de incorporar al análisis la gravedad de las penas concurrentes $^{61}$, y por un baremo de carácter mixto (cuantitativo y cualitativo) que admite la gravedad como factor a evaluar en la determinación de la pena menor, sin renunciar a su medición cuantitativa ${ }^{62}$; debate que se ha centrado en la interpretación de la expresión pena menor y en si su significado normativo admite o excluye consideraciones cualitativas.

En tanto normalmente el criterio cuantitativo resuelve adecuadamente lo que en el caso concreto constituye una pena menor, primando en la generalidad de los casos el sistema de exasperación por establecer una pena más benigna ${ }^{63}$ (así, dos penas de diez años y un día de

\footnotetext{
${ }^{60}$ La doctrina y jurisprudencia es conteste en advertir que pese a la expresión podrá contenida en el inciso tercero de la regla de reiteración, la aplicación preferente del sistema de acumulación material resulta obligatoria si a través del mismo se deriva la imposición de una pena menor; así, por todos, CURY URZÚA, Derecho penal, cit. nota $\mathrm{n}^{\circ} 7$, p. 661.

${ }^{61}$ MATUS ACUÑA, "Proposiciones", cit. nota n 1, p. 538.

${ }^{6}$ OLIVER CALDERÓN, “La exasperación”, cit. nota ${ }^{\circ}$ 9, p. 181.

${ }^{63}$ Al margen de tal regla general, es perfectamente posible que desde una óptica cuantitativa el régimen de acumulación material en el caso concreto provea de una pena múltiple más favorable al condenado que la pena única derivada del régimen de exasperación. Así, por ejemplo, la STOP Punta Arenas Rit 14-2015, de 06/05/2015, frente a dos delitos consumados de lesiones graves y lesiones menos graves, ambos con una circunstancia agravante y una atenuante ordinaria, las que compensó y anuló recíprocamente, decidió correctamente que "[e]xistiendo reiteración de hechos punibles, al imputado se le aplicará la norma del artículo 74 del Código Penal, esto es, se le impondrá una pena por cada delito, por ser más favorable para él,
} 
presidio mayor en su grado medio -veinte años y dos días conjuntamente- constituyen globalmente una pena mayor que una pena única de quince años y un día de presidio mayor en su grado máximo); el problema se presenta en los supuestos en que -desde una óptica cualitativa - la clase de sanción aplicable para la pluralidad de penas derivadas de la acumulación material, pese a una mayor extensión temporal objetiva de la sumatoria de todas ellas, supone una afectación de menor intensidad que la que importa la clase de pena única que ofrece el sistema de reiteración no obstante su menor extensión temporal. Así, por ejemplo, la dualidad existente entre, por una parte, una pena única de cinco años y un día de presidio mayor en su grado mínimo en régimen de cumplimiento efectivo conforme al sistema de acumulación jurídica y, por la otra, dos penas de tres años y un día de presidio menor en su grado máximo derivadas del sistema de acumulación material, susceptibles ambas -en principio- de ser sustituidas por la pena de libertad vigilada intensiva, de cumplimiento en el medio libre.

Actualmente, al menos en su aspecto formal, el problema debiese entenderse zanjado por la instauración normativa de penas sustitutivas en reemplazo de los anteriores beneficios alternativos en la Ley 18.216, en tanto las penas sustitutivas son penas y, por ello, susceptibles de constituir una pena menor para los efectos del inciso tercero del art. 351 del Código Procesal Penal.

Asimismo, la inclusión en el análisis de la gravedad de las penas derivadas de uno u otro sistema es perfectamente admisible en tanto el baremo que preside la comparación entre ambas exige una ponderación de la carga punitiva que resulta posible de asignar, ponderación - de la afectación de los derechos del condenado a través de la sanción penalen la que incide no sólo la extensión o duración de la pena, sino que también su forma de ejecución. Dado que el objetivo que orienta la comparación está constituido por la elección de la respuesta penal menos intensa de entre aquellas posibles, la inclusión de la mayor o menor gravedad de la pena aplicable como factor a evaluar deviene no sólo en pertinente, sino que también en necesaria.

Para los efectos de la decisión sobre el régimen aplicable -acumulación material o jurídicaambos criterios (cuantitativo y cualitativo) deben incidir de forma conjunta a través de la siguiente directriz general, tratándose de penas privativas de libertad: siempre constituirá una pena menor aquella sanción cuya extensión sea inferior, salvo que su forma de ejecución implique una afectación más intensa de los derechos del condenado no obstante su menor extensión objetiva, supuesto en el cual deberá optarse por la clase de sanción alternativa que importe una forma de cumplimiento menos gravosa (como ocurre precisamente tratándose de penas sustitutivas).

Al margen de ello, se presenta el problema asociado a la admisibilidad normativa de imposición en una misma sentencia de más de una pena sustitutiva, en el supuesto de estimarse como preferente la aplicación del régimen de acumulación material por ser más favorable precisamente en razón de la posibilidad de condena a través de una pena

que la del artículo 351 del Código Procesal Penal, ya que de aplicar esta última, para precisar la pena corporal única sería necesario elevar la pena privativa de libertad por las lesiones graves, en un grado, por la reiteración, lo que sería más gravoso para aquél”. 
BESIO, Martín. “Aplicación del artículo 351 del Código Procesal Penal”.

sustitutiva respecto de cada una de las infracciones que integran la pluralidad de delitos en concurso real, pese a la objetiva mayor extensión que suponen sus penas originales en conjunto. La cuestión es relevante dado que sólo la posibilidad de aplicación de penas sustitutivas respecto de cada uno de los delitos en reiteración es la que condiciona la vigencia subsidiaria - por ser más favorable atendida la clase de sanción aparejada- del art. 74 del Código Penal.

Dicho problema puede ilustrarse adecuadamente por medio de dos sentencias dictadas por un mismo tribunal, con tan sólo unos meses de diferencia entre ambas, que adoptan posiciones disímiles al respecto.

Por una parte, la SCA Concepción Rol 253-2014, de 30/05/2014, que en el escenario de dos delitos de robo con intimidación (uno consumado y el otro frustrado) decide -al tenor exclusivo de un baremo cuantitativo- la aplicación del régimen de exasperación dada la menor extensión de la pena determinada conforme al mismo, excluyendo del análisis comparativo con el régimen de acumulación material la posibilidad de imposición a su alero de dos penas de libertad vigilada, dado que para esos efectos “(...) cabe considerar las penas como un todo y no en forma fraccionada, razón por la cual faltaría de todos modos en el escenario hipotético que [se] propone el requisito objetivo relativo al quantum de la sanción temporal que hace procedente dicha pena sustitutiva". El razonamiento relevante es el siguiente:

"Que, entonces, malamente puede discurrirse sobre la base de una infracción de ley en la forma en que los jueces del mérito fijaron la pena única impuesta de cinco años y un día de presidio mayor en su grado mínimo, en la medida que esta pena es cuantitativamente menor que haber impuesto dos penas de tres años un día de presido menor en su grado máximo, las que, sumadas, arrojan la cantidad de seis años y dos días de sanción temporal.

Evidentemente, y tal como se expuso en el motivo vigésimo tercero de la sentencia impugnada, resulta ser más favorable para Figueroa Parra aplicarle el régimen del artículo 351 del Código Procesal Penal, es decir, el mencionado sistema de acumulación jurídica y no el de suma de penas.

Que la conclusión anterior no sufre alteración alguna con la posible pena sustitutiva que pudo aplicársele a dicho incriminado, como quiera que para los efectos de la libertad vigilada intensiva de que habla el recurrente cabe considerar las penas como un todo y no en forma fraccionada, razón por la cual faltaría de todos modos en el escenario hipotético que propone el requisito objetivo relativo al quantum de la sanción temporal que hace procedente dicha pena sustitutiva".

Por el contrario, cinco meses después, la SCA Concepción Rol 523-2014, de 03/10/2014, adoptó un criterio inverso, decidiendo respecto de uno de los condenados por dos delitos de robo con fuerza la aplicación del régimen de acumulación material por ser más favorable dada precisamente la posibilidad de imposición de dos penas sustitutivas de libertad vigilada intensiva, las que impone - una vez acogida la nulidad- en sentencia de reemplazo. El análisis es el siguiente:

"Que, en la lógica de las disposiciones en juego (artículo 351 inciso $2^{\circ}$ del Código Procesal Penal y 74 del Código Penal), resulta ser efectivo lo sostenido por las 


\section{Polít. crim. Vol. 10, № 20 (Diciembre 2015), Art. 5, pp. 543-596. \\ [http://www.politicacriminal.cl/Vol_10/n_20/Vol10N20A5.pdf]}

defensas de los sentenciados, en orden a que debe aplicarse la regla del artículo 74 del Código Penal, por ser ella más favorable a los sentenciados.

En efecto, en el caso del sentenciado adulto (Salazar Rivera) de seguirse el mecanismo contemplado en el artículo 74 ya referido, se le pudo haber sancionado con dos penas de tres años y un día de presidio menor en su grado máximo cada una y, en cada caso, aplicarle la pena de libertad vigilada intensiva, ya que el informe de Gendarmería era favorable. A tal conclusión se llega por cuanto la pena contemplada en el artículo 440 $\mathrm{n}^{\circ} 1$ del Código Penal para el delito de robo con fuerza en lugar destinado a la habitación, es de presidio mayor en su grado mínimo (cinco años y un día a diez); al tener el acusado dos atenuantes, y ninguna agravante, ya que la tercera atenuante se le compensó con la única agravante que concurría, se le puede rebajar la pena en un grado y se tiene una pena de presidio menor en su grado máximo, de tres años y un día por cada delito, pudiendo aplicársele la pena sustitutiva de la libertad vigilada intensiva en cada caso. En cambio, con la regla del artículo 351 del Código Procesal Penal, la pena de presidio menor en su grado máximo (tres años y un día) se debe aumentar en un grado, llegando a la de presidio mayor en su grado máximo (de cinco años y un día a diez años), sin que por la extensión de la pena le sea posible al Tribunal aplicar pena sustitutiva alguna".

No obstante que a partir de una concepción tradicional del fin preventivo-especial (indisolublemente vinculado con la Ley 18.216) es posible defender la exclusión de aplicación conjunta en una misma sentencia de más de una pena sustitutiva, en tanto la comisión de una pluralidad de delitos puede estimarse como indiciaria de peligrosidad criminal y, por ello, dicha aplicación devenir en inconsistente con tal finalidad; dado el contexto de irracionalidad que subyace al pronóstico de peligrosidad criminal $^{64}$ y a sus baremos de medición, la operatividad del cometido preventivo-especial debe ser encausada a través de la (más modesta, pero racional) pretensión de no-desocialización del condenado, en tanto correlato necesario del principio de intervención mínima (de reducción de la propia violencia estatal, a fin de cuentas), que exige una maximización del uso de la pena privativa de libertad, esto es, su exclusión siempre cuando ello sea posible, especialmente por medio de su sustitución por formas de ejecución menos lesivas ${ }^{65}$ de los derechos del condenado ${ }^{66}$. Dicha perspectiva reafirma la posibilidad de imposición conjunta de penas sustitutivas para una pluralidad de delitos en concurso real.

Al mismo tiempo, no existe ninguna disposición en la Ley 18.216 que limite de modo explícito la procedencia de penas sustitutivas al supuesto exclusivo de existencia en un proceso de un solo delito y de una sola pena, por lo que si -como entiende Matus Acuña-

\footnotetext{
${ }^{64}$ Sobre la operatoria de la prevención especial en la individualización de la pena, sus deficiencias y el cometido de no-desocialización, BESIO HERNÁNDEZ, Criterios, cit. nota nº 56, pp. 407-419.

${ }^{65}$ En el mismo sentido, CURY URZÚA, Enrique, "La prevención especial como límite de la pena", ADPCP (1988), pp. 685-702, p. 696.

${ }^{66}$ Tal objetivo preventivo de no-desocialización del condenado a través de una maximización de la evitación de la pena privativa de libertad tiene -por lo demás- un reflejo concreto en la Ley 18.216 y en las consecuencias que ésta asigna al incumplimiento del régimen de ejecución de las propias penas sustitutivas, al establecer (art. 25) en caso de incumplimiento grave o reiterado de éstas la posibilidad de su reemplazo por otra pena sustitutiva de mayor intensidad. y en el supuesto de otros incumplimientos una intensificación primaria de las condiciones -a través del establecimiento de mayores controles de cumplimiento- de la pena sustitutiva del caso; esto es, en definitiva, una escala gradual de intensidad progresiva que tiende a limitar la ejecución efectiva de la pena privativa de libertad.
} 


\section{BESIO, Martín. “Aplicación del artículo 351 del Código Procesal Penal”.}

“(...) la literalidad de los artículos de la Ley 18.216, parecen restringir su potencial aplicación a los casos en que se impone una pena por un único hecho punible (...),67, tal aparente presupuesto normativo se explica por la sencilla razón de que la determinación de la pena asociada a un delito -incluida la procedencia de una eventual pena sustitutivaopera respecto de cada delito y su sanción individualmente considerados y no en su relación con otros delitos y sus penas (a menos que una regla prevea una ponderación conjunta, como en los casos de los arts. 75 del Código Penal y 351 del Código Procesal Penal, que de todas formas generan una pena única que debe ser determinada $y$, eventualmente, sustituida), por lo que la Ley 18.216 opera sobre la base implícita del establecimiento positivo de requisitos de procedencia de cada sustitutivo penal con respecto a cada delito y pena en particular.

La consagración en la Ley 18.216 de requisitos de procedencia de las penas sustitutivas asignados formalmente a la existencia de una sola sanción debe entenderse referida a cada una de las penas individualmente consideradas susceptibles de sustitución, admitiendo la posibilidad normativa de imposición de más de una pena sustitutiva en el evento de que cada una de las sanciones asignadas a cada uno de los delitos satisfagan -individualmentesus requisitos de procedencia.

Además, en tanto las penas concurrentes se individualizan particularmente (y no de modo global) deviene en improcedente la sumatoria de las cuantías de las sanciones asignadas a cada delito que integra la pluralidad para los efectos de una eventual decisión sobre procedencia (individual) de sustitutivos penales; amén de que dicho procedimiento de adición o suma hipotética no tiene asidero normativo alguno en la Ley 18.216, no obstante una discutible práctica judicial en esa línea.

\subsection{Reiteración y prescripción de la acción penal.}

El análisis de una eventual prescripción (o prescripción gradual) de la acción penal de todos o de algunos de aquellos ilícitos que integren una pluralidad de delitos de una misma especie en relación de concurso real, puede plantear algunas dificultades teóricas frente a su reconducción potencial a través de la regla del art. 351 del Código Procesal Penal; escenario en el que cabe dilucidar cómo se relaciona dicha regla con el instituto de la prescripción. Así, por ejemplo, piénsese en simples delitos ${ }^{68}$ de una misma especie

\footnotetext{
${ }^{67}$ MATUS ACUÑA, "Proposiciones", cit. nota $n^{\circ}$ 1, p. 539, aunque respecto de la Ley 18.216 en su texto vigente con antelación a las modificaciones introducidas por la Ley 20.603 (n. 41), y advirtiendo -en todo caso- que "(...) la práctica de nuestros tribunales parece no ir en esa dirección”.

${ }^{68} \mathrm{Al}$ margen del problema de determinar el plazo de prescripción aplicable respecto de aquellos delitos que tienen asignados marcos penales compuestos por penas de simple delito y crimen, escenario en que la jurisprudencia - con el apoyo de la doctrina- suele aplicar analógicamente el criterio de gravedad (pena mayor) previsto expresamente por el art. 94 del Código Penal para la hipótesis de penas integradas por sanciones no privativas de libertad, extendiéndolo a aquellas penas compuestas por sanciones privativas de libertad, escenario este último no reglado por el legislador en el texto vigente de dicha norma (sí con anterioridad a la Ley 18.857 , de 06/12/1989) y que determina en perjuicio del condenado -por lo que se trata de analogía prohibida- la aplicación del plazo de prescripción propio de la pena de crimen. Entre otras, en esa línea, las SCS Rol 4796-2007, de 08/01/2007; y SCS Rol 1556-2012, de 08/10/2012. En la doctrina, amparando el criterio de gravedad y sin advertir el problema, entre otros, ETCHEBERRY, Derecho penal, cit.
} 
ejecutados sucesivamente durante un largo período de tiempo, en términos tales que verificada la suspensión de la prescripción de la acción penal (por ejemplo, mediante la interposición de una querella) ${ }^{69}$ algunos de ellos -individualmente considerados- se encontrarían fuera del período de cinco años contados desde la fecha de suspensión en retrospectiva y, por tanto, prescrita la acción penal, mientras que respecto de otros habría transcurrido más de la mitad del tiempo de prescripción sin que éste se haya completado, verificándose los presupuestos de la prescripción gradual a su respecto, y otros tan cercanos temporalmente a la fecha de suspensión que no cabría plantear la procedencia de la prescripción ni de la media prescripción.

En tanto se trate de una pluralidad de delitos de una misma especie en concurso material que satisfaga los presupuestos de la regla de reiteración delictiva, la pregunta que cabe formular es si dicha regla resulta compatible con la prescripción individual de los delitos que integran la pluralidad y si, en su caso, la reiteración delictiva se sujeta o no a reglas o principios especiales en cuanto al cómputo de la prescripción. La posibilidad de interrupción del curso de prescripción mediante la ejecución de los ilícitos posteriores al primero (y cada delito posterior a su antecesor) con el efecto normativo de eliminar el tiempo ya transcurrido, es otra variable a considerar en tanto suele asimilarse con el sistema de reiteración, confundiéndose, en definitiva, ambas categorías.

Al respecto, una primera cuestión a destacar es que la reiteración delictiva no constituye una hipótesis de unidad delictiva o de unidad jurídica de comportamiento, pese a una cierta simetría estructural con algunas categorías delictivas que la doctrina suele reconocer bajo esa nomenclatura ${ }^{70}$, como el -discutible caso del- delito continuado y el delito habitual ${ }^{71}$, en tanto su presupuesto base es precisamente una pluralidad de delitos fáctica y normativamente independientes (en concurso material), esto es, una pluralidad de delitos autónomos. Si bien el tenor literal del art. 351 del Código Procesal Penal y el sistema de cuantificación que contiene se orienta a aunar los delitos que se integran a su alero (en general, la consideración de las diferentes infracciones "estimadas como un solo delito", el sistema de individualización sobre la base de la pena de una sola de las infracciones que componen la reiteración y la respuesta penal única - una sola pena- asignada a la pluralidad delictiva), dicha unificación se materializa sólo para los efectos de cuantificación de la pena y bajo el objetivo específico de morigerar la respuesta penal primaria frente a delitos independientes- que comparten el mismo objeto de protección. Se trata, en definitiva, de una pluralidad de delitos que son unificados por una regla de individualización de la pena para el sólo efecto de la cuantificación punitiva, por lo que incluso al interior del régimen

nota $\mathrm{n}^{\circ}$ 26, p. 258; CURY URZÚA, Derecho penal, cit. nota $\mathrm{n}^{\circ}$ 7, p. 800; ORTIZ/ARÉVALO, Consecuencias, cit. nota $\mathrm{n}^{\circ} 41$, p. 527.

${ }^{69}$ Así lo ha entendido la jurisprudencia mayoritaria; entre otras, las SCS Rol 24.990-2014, de 08/01/2015; SCS Rol 7815-2012, de 26/12/2012; SCA La Serena Rol 375-2014, de 03/11/2014; y SCA San Miguel Rol 665-2011, de 06/06/2011. En contra, circunscribiendo la suspensión de la prescripción sólo al acto de formalización de la investigación, las SCA Santiago Rol 2858-2014, de 28/10/2014; y SCA Talca Rol 4372011, de 21/12/2011.

${ }^{70} \mathrm{Al}$ respecto, COUSO SALAS, “Comentario", cit. nota n ${ }^{\circ} 1$, pp. 632 y ss.

${ }^{71}$ Respecto de los cuales existe acuerdo mayoritario en que el tiempo de prescripción comienza a transcurrir “(...) desde que se comete el último de los hechos típicos integrantes del conjunto”, CURY URZÚA, Derecho penal, cit. nota $\mathrm{n}^{\circ} 7, \mathrm{p} .801$. 
BESIO, Martín. “Aplicación del artículo 351 del Código Procesal Penal”.

de reiteración constituyen delitos normativamente independientes (son, en definitiva, delitos reiterados - en plural-y no un delito reiterado -en singular) que se sancionan bajo un régimen especial privilegiado.

De ahí que la reiteración de delitos no sea incompatible con la prescripción individual de los delitos que la integran y que, en consecuencia, dicho régimen no se sujeta a reglas especiales -en tanto una suerte de unidad global reiterada- en materia de prescripción de la acción penal, como sí ocurre tratándose de ciertas hipótesis de unidad delictiva en que el término del cómputo se inicia a partir del día de comisión de la última infracción que la constituye. Asimismo, cada uno de los delitos mantiene de forma autónoma el plazo de prescripción que le corresponde en virtud del art. 94 del Código Penal, pese a su estimación conjunta definitiva, en su caso, al interior del régimen de reiteración. Ello implica, en la práctica, que en un escenario de sucesión en el tiempo de varios delitos en concurso material pueda verificarse la prescripción respecto de sólo algunos de ellos -de aquellos en que se verifiquen los requisitos de prescripción- y de todas formas tratándose de los restantes configurarse una reiteración de delitos bajo el sistema del art. 351 del Código Procesal Penal. La posibilidad no es trivial, pues si bien en algunos casos la incidencia de la prescripción individual de algunos delitos no será determinante en la pena resultante del régimen de reiteración, dado que de todas formas existirá reiteración de delitos y ésta opera sobre la base de la pena mayor asignada a una de las infracciones en reiteración más el aumento del caso (por lo que podría sostenerse que los delitos prescritos no alterarían la pena en definitiva impuesta), sí influye en la disminución del número de delitos reiterados y, por ello, en su caso, en la decisión de aumento potestativo del segundo grado. Asimismo, podrá incidir de modo relevante si el número de los delitos respecto de los que se ha verificado la prescripción determina que el sistema de exasperación ceda frente al régimen subsidiario de acumulación material de las penas, en tanto por su intermedio sea posible la imposición de una pena menor ${ }^{72}$. Del mismo modo, la prescripción gradual de algunas infracciones - como regla general- no será determinante en la aplicación del régimen de reiteración, toda vez que (a menos que ésta se verifique respecto de todas ellas) la base del cálculo de pena está constituida por la pena mayor de entre aquellas asignadas, con todas sus circunstancias, a los delitos que se subordinan al sistema, ponderación -para la determinación de la pena mayor base del cálculo- en que incide la configuración de dos atenuantes muy calificadas, sin agravantes (en caso de que se presenten).

Otro problema distinto (que suele emparentarse con la reiteración como si fuesen parte de una misma categoría) es la posibilidad teórica de interrupción de la prescripción al interior de una pluralidad sucesiva de delitos de una misma especie como consecuencia de la ejecución de cada delito posterior al primero, eliminándose el tiempo transcurrido progresivamente respecto del antecesor y con ello, en principio, toda posibilidad de prescripción.

En tal escenario, la solución dependerá de los requisitos que se asignen a la verificación de la hipótesis normativa de comisión de un nuevo -crimen o simple-delito prevista en el art. 96 del Código Penal, que conlleva la interrupción de la prescripción y, por ello, la pérdida del tiempo transcurrido y la generación de un nuevo término de prescripción a partir de su

\footnotetext{
${ }^{72} \mathrm{Al}$ respecto, supra 2.5.
} 
fecha de comisión. Se trata de un problema de interpretación de la expresión "siempre que el delincuente comete nuevamente crimen o simple delito", hipótesis que admite -ante un escaso desarrollo dogmático y en ausencia de criterios explícitos que precisen su sentidovarias posibilidades de concreción.

Sobre este punto, si bien existe consenso dogmático en exigir una sentencia judicial ejecutoriada que establezca el nuevo delito y la responsabilidad del autor en el mismo ${ }^{73}$ (lo que resulta lógico en tanto la existencia indubitada de un hecho punible sólo puede declararse por sentencia judicial), un sector de la doctrina admite que -conforme al hoy derogado art. 160 del Código Orgánico de Tribunales " ${ }^{74}$ “...) el conocimiento de ambos procesos, acumulados, corresponderá a un mismo tribunal" ${ }^{75}$, aceptando la posibilidad de que el establecimiento judicial del nuevo delito (de aquél que produce el efecto de interrupción de la prescripción de un ilícito antecesor) se verifique en el mismo proceso en que se declara la existencia del delito cuyo cómputo de prescripción se interrumpe (del delito antecesor); con lo que -en definitiva- se admite en la práctica la imprescriptibilidad de delitos cuya acción penal es susceptible de prescripción, al no sujetar a límite temporal alguno la posibilidad de interrupción de su cómputo (así, por ejemplo, extremando las posibilidades, bastará con que un sujeto ejecute un simple delito cada cuatro años y once meses durante un período de veinte años, para que todos los delitos de esa secuencia, incluido el primero de ellos ejecutado dos décadas atrás, sea objeto de condena en el mismo proceso que las infracciones que sucesivamente han interrumpido una y otra vez la prescripción a su respecto, generándose progresivamente como época del cómputo de la prescripción de todos los delitos el día de comisión del último de aquellos, que corresponde al ilícito respecto del cual, en el ejemplo, se ha verificado la suspensión de la prescripción) $)^{76}$.

La indeterminación procesal que conlleva esta interpretación en algunos escenarios y su inconsistencia con el fundamento material de la prescripción -la eliminación de la necesidad de pena por el transcurso del tiempo respecto de cada delito en forma individualhacen preferible una aproximación diferente, exigiéndose que el plazo de prescripción asociado a un delito se erija como el término máximo durante el cual debe establecerse judicialmente la existencia del nuevo delito que adquiere -en ese evento- la eficacia de interrumpir la prescripción del delito antecesor. Se trata, en definitiva, de limitar la posibilidad de verificación procesal del delito que genera la interrupción de la prescripción

\footnotetext{
${ }^{73}$ Así, entre otros, además de infra n. 75, CURY URZÚA, Derecho penal, p. 802, cit. nota n ${ }^{\circ}$; GARRIDO MONTT, Derecho penal, cit. nota ${ }^{\circ} 7$, p. 394.

${ }^{74}$ La derogación del art. 160 del Código Orgánico de Tribunales no debiese incidir en una variación del sentido del argumento al tenor del -vigente- art. 185 del Código Procesal Penal, a menos que de dicha regla se pretenda derivar un imperativo procesal de conocimiento conjunto, como pareciera sugerirlo NOVOA MONREAL, Curso, cit. nota $\mathrm{n}^{\circ} 30$, p. 405.

75 GUZMÁN DÁlBORA, José Luis, “Artículo 96”, en: POLITOFF, Sergio; ORTIZ, Luis (Dirs.), Texto y Comentario del Código Penal chileno, t. I, Santiago: Ed. Jurídica, 2002, pp. 472-477, p. 474; en la misma línea, YUSEFF SOTOMAYOR, Gonzalo, La prescripción penal, $3^{\circ}$ ed., Santiago: Editorial Jurídica, 2005 , p. 111; y NOVOA MONREAL, Curso, cit. nota ${ }^{\circ} 30$, p. 405.

${ }^{76}$ En esa línea, aparentemente, GARRIDO MONTT, Derecho penal, cit. nota n ${ }^{\circ}$ 7, p. 394; CURY URZÚA, Derecho penal, cit. nota $\mathrm{n}^{\circ} 7$, p. 802.
} 
BESIO, Martín. “Aplicación del artículo 351 del Código Procesal Penal”.

al estadio temporal constituido por el término de prescripción del delito precedente ${ }^{77}$, ya sea en un mismo o diferente procedimiento, generándose así al amparo del propio sistema de interrupción un mecanismo de control -consistente con el tenor del art. 96 del Código Penal- que limita la posibilidad de interrupciones sucesivas que, en la práctica, instauren un régimen de imprescriptibilidad encubierta.

Tal restricción puede derivarse de la regulación de la interrupción de la prescripción de la pena, en tanto el art. 99 del Código Penal limita -para los efectos de la interrupción del cómputo- la comisión del nuevo ilícito al interior del término de prescripción de la pena ("durante ella"), iniciado en este caso desde la sentencia de término o desde el quebrantamiento de la condena; sin que se advierta una razón suficiente que justifique un tratamiento diferenciado para ambas hipótesis de interrupción (de la acción penal y de la pena) en tanto ambas dependen del mismo presupuesto objetivo, a saber, la comisión de un nuevo crimen o simple delito ${ }^{78}$. En la medida que el nuevo ilícito-que produce el efecto de interrupción- debe establecerse judicialmente mediante sentencia ejecutoriada, para tener la eficacia de interrumpir el cómputo del tiempo de prescripción - de la acción penal y de la pena- ésta deberá dictarse dentro de dicho término.

\footnotetext{
77 Así, sobre la base de esa exigencia, la SCA Santiago Rol 1020-2013, de 20/06/2013, respecto de la configuración de la prescripción gradual del primer delito.

${ }^{78}$ NOVOA MONREAL, Curso, cit. nota ${ }^{\circ}$ 30, p. 412: "[e]s una interrupción enteramente análoga a la que experimenta la prescripción de la acción penal”.
} 
Polít. crim. Vol. 10, No 20 (Diciembre 2015), Art. 5, pp. 543-596.

[http://www.politicacriminal.cl/Vol_10/n_20/Vol10N20A5.pdf]

\section{BIBLIOGRAFÍA}

BESIO HERNÁNDEZ, Martín, Los criterios legales y judiciales de individualización de la pena, Valencia: Ed. Tirant lo Blanch, 2011.

CONTRERAS GUERRERO, Pablo, "Una tesis para entender la medida de la pena en los casos de reiteración de delitos de la misma especie: análisis de las reglas penológicas contenidas en el artículo 351 del Código Procesal Penal a la luz del Principio de Proporcionalidad Constitucional", Polit. crim. vol. 9, $\mathrm{N}^{\circ} 18$ (diciembre 2014), pp. 614-667,

en: http://www.politicacriminal.cl/Vol_09/n_18/Vol9N18A10.pdf

COUSO SALAS, Jaime, "Comentario previo a los Arts. 74 y 75 . El régimen concursal en el derecho chileno. Tratamiento doctrinario y jurisprudencial", en: COUSO, Jaime; HERNÁNDEZ. Héctor (Dirs.), Código Penal comentado, parte general. Doctrina y jurisprudencia, Santiago: Ed. AbeledoPerrot, 2011, pp. 625-666.

, "Comentario previo a los Arts. 50 a 69 y 76 a 78. El sistema de determinación de penas en el derecho chileno", en: COUSO, Jaime; HERNÁNDEZ, Héctor (Dirs.), Código Penal comentado, parte general. Doctrina y jurisprudencia, Santiago: Ed. AbeledoPerrot, 2011, pp. 510-544.

, “Artículo 66", en: COUSO, Jaime; HERNÁNDEZ, Héctor (Dirs.), Código Penal comentado, parte general. Doctrina y jurisprudencia, Santiago: Ed. AbeledoPerrot, 2011, pp. 539-897.

CURY URZÚA, Enrique, Derecho Penal, parte general, $10^{\circ}$ ed., Santiago: Ed. Universidad Católica de Chile, 2011. ,"La prevención especial como límite de la pena", ADPCP (1988), pp. 685-702.

CHOCLÁN MONTALVO, José Antonio, Individualización judicial de la pena. Función de la culpabilidad y la prevención en la determinación de la sanción penal, Madrid: Ed. Colex, 1997.

ETCHEBERRY, Alfredo, Derecho Penal, parte general, t. II, $3^{\circ}$ ed., Santiago: Editorial Jurídica, 1998.

GARRIDO MONTT, Mario, Derecho Penal, parte general, t. I., $2^{\circ}$ ed., Santiago: Editorial Jurídica, 2005.

Derecho Penal, parte general, t. II, $3^{\circ}$ ed., Santiago: Editorial Jurídica, 2003.

GUZMÁN DÁLBORA, José Luis, “Artículo 96", en: POLITOFF, Sergio; ORTIZ, Luis (Dirs.), Texto y Comentario del Código Penal chileno, t. I, Santiago: Editorial Jurídica, 2002, pp. 472-477.

MATUS, Jean Pierre; RAMÍREZ, M. Cecilia, Lecciones de Derecho Penal chileno, parte especial, Santiago: Ed. Legal Publishing, 2014.

MATUS ACUÑNA, Jean Pierre, "Proposiciones respecto de las cuestiones no resueltas por la ley 20.084 en materia de acumulación y orden de cumplimiento de las penas", Ius et Praxis, v. 2 (2008), pp. 285-306, en: http://www.scielo.cl/pdf/iusetp/v14n2/art15.pdf

"Artículo 77", en: POLITOFF, Sergio; ORTIZ, Luis (Dirs.), Texto y Comentario del Código Penal chileno, t. I, Santiago: Ed. Jurídica, 2002, pp. 403-407.

MIR PUIG, Santiago, Derecho Penal, parte general, $9^{\circ}$ ed., Barcelona: Ed. Reppertor, 2011. 
BESIO, Martín. “Aplicación del artículo 351 del Código Procesal Penal”.

NOVOA MONREAL, Eduardo, Curso de Derecho Penal chileno, parte general, t. II, $3^{\circ}$ ed., Santiago: Editorial Jurídica, 2005.

OLIVER CALDERÓN, Guillermo, "La exasperación de la pena en el concurso material de delitos: la reiteración de delitos de la misma especie", Revista de Derecho (Valdivia), vol. 26, $\mathrm{n}^{\circ} 2$ (2013), pp. 167-188 en: http://www.scielo.cl/pdf/revider/v26n2/art07.pdf

"Aproximación a la unificación de penas", Polit. crim. vol. 7, $\mathrm{N}^{\circ} 14$ (diciembre 2012), pp. 248-275, en: http://www.scielo.cl/pdf/politcrim/v7n14/art01.pdf.

ORTIZ, Luis; ARÉVALO, Javier, Las Consecuencias Jurídicas del delito, Santiago: Editorial Jurídica, 2013.

POLITOFF, Sergio; MATUS, Jean Pierre; RAMÍREZ, M. Cecilia, Lecciones de Derecho Penal chileno, parte general, Santiago: Ed. Jurídica, 2011.

SOLARI, Tito; RODRÍGUEZ, Luis, "Determinación de la pena en los casos de reiteración de delitos (Ámbito de aplicación del art. 509 del Código de Procedimiento Penal)", Revista de Derecho, Pontificia Universidad Católica de Valparaíso, vol. III (1979), pp. 255-271.

YUSEFF SOTOMAYOR, Gonzalo, La prescripción penal, $3^{\circ}$ ed., Santiago: Editorial Jurídica, 2005. 